A GNIESZKA BASZKO

Biblioteka Raczyńskich w Poznaniu,

Dział Zbiorów Specjalnych

\title{
Podróż naukowa Karola Libelta do Galicji w 1869 roku i rękopiśmienna pamiątka po niej w zbiorach Biblioteki Raczyńskich w Poznaniu
}

\begin{abstract}
Streszczenie. W 2012 roku przekazano do zbiorów specjalnych Biblioteki Raczyńskich w Poznaniu rękopiśmienny album (sygn. Rkp. 4498) będący pamiątką z podróży naukowej Karola Libelta do Galicji w 1869 roku. Filozof odwiedził wówczas z wykładami Kraków i Lwów, był serdecznie przyjmowany przez mieszkańców obu miast. 17 kwietnia 1869 roku młodzież akademicka wręczyła Libeltowi w podziękowaniu i w dowód uznania album z kartami zawierającymi 348 podpisów słuchaczy Uniwersytetu Jagiellońskiego i Instytutu Technicznego w Krakowie. Artykuł zawiera opis podróży Karola Libelta do Galicji oraz albumu z wpisami krakowskich studentów, m.in. Michała Hieronima Bobrzyńskiego, Karola Stanisława Olszewskiego, Tadeusza Browicza, Józefa Krzepeli czy Piotra Hubala Dobrzańskiego.
\end{abstract}

Słowa kluczowe: Karol Libelt (1807-1878), podróż naukowa do Galicji w 1869 roku, Kraków, Lwów, Uniwersytet Jagielloński, Instytut Techniczny w Krakowie, Polska XIX wieku, Biblioteka Raczyńskich w Poznaniu, rękopisy, albumy pamiątkowe.

Koniec lat 60. XIX wieku przyniósł znaczący zwrot w życiu i działalności Karola Libelta. W 1868 roku oddał majątek Czeczewo w dzierżawę swojemu synowi Pantaleonowi i jednocześnie powoli wycofywał się $\mathrm{z}$ pracy posła $\mathrm{w}$ sejmie pruskim. Rezygnacja $\mathrm{z}$ tych dwóch absorbujących aktywności - zarządzania majątkiem i spełniania obowiązków parlamentarnych - pozwoliła mu ponownie poświęcić się działalności naukowej i publicystycznej. Istotnym wydarzeniem w życiu Libelta był jego wybór 23 marca 1868 roku na stanowisko prezesa poznańskiego Towarzystwa Przyjaciół Nauk. Towarzystwo pod jego kierunkiem przeżywało okres rozkwitu: "Jako prezes [...] nie tylko inicjował i realizował kilka większych prac, które umacniały imię poznańskiej instytucji 
naukowej, lecz świetnie reprezentował ją na zewnątrz" ${ }^{11}$. Libelta zapraszano na różne uroczystości z racji pełnionej przez niego funkcji, ale przede wszystkim w uznaniu jego sławy wybitnego uczonego, filozofa i zasłużonego patrioty.

W listopadzie 1868 roku Towarzystwo Naukowo-Literackie we Lwowie zaproponowało Libeltowi odczyty $\mathrm{w}$ ramach organizowanego przez siebie cyklu wykładów, zaplanowanych na przełomie 1868 i 1869 roku. Wiceprezes Henryk Schmitt tak zwracał się do Libelta:

Zawiązane w bieżącym roku towarzystwo naukowo-literackie we Lwowie postanowiło urządzić $\mathrm{w}$ ciagu zimy wykłady publiczne w przedmiotach naukowych i literackich, licząc $w$ tym na pomoc mężów uprawiających niwę nauk i piśmiennictwa, znakomite $\mathrm{w}$ świecie naukowym zajmujących stanowisko. $\mathrm{W}$ tej myśli mam zaszczyt na mocy uchwały Wydziału towarzystwa zaprosić Szanownego Pana, abyś także zechciał mieć jeden lub dwa wykłady w gronie naszym, $\mathrm{w}$ przedmiocie przez siebie wybranym ${ }^{2}$.

Zgodnie z oczekiwaniami Schmitta Libelt jako „gorliwy zwolennik sprawy naukowej" nie odmówił i z entuzjazmem odniósł się do propozycji:

Stanowisko, które dziś Galicja wobec Austrii, a stąd i wobec Polski zajęła, jest tak ważne i tak wiele obiecujące, że mu się z bliska przypatrzeć ciekawość bierze każdego, kto z upragnieniem lepszej doli dla kraju wygląda. Poznanie osobiste znakomitości literackich, politycznych we Lwowie jest dziś podwójnego interesu. Obok tego sama myśl przez odczyty na ten sposób urządzone stworzyć wspólne duchowe ognisko trzech dzielnic rozdzielonej Polski, była szczęśliwym pomysłem, któremu nie należy dać upaść, ale je urzeczywistniać, ile się da, potrzeba ${ }^{3}$.

Dodatkowo w lutym 1869 roku z prośbą o odczyt zwróciło się do Libelta Muzeum Techniczno-Przemysłowe w Krakowie ${ }^{4}$, na co filozof przystał.

${ }^{1}$ Z. Grot, Życie i działalność Karola Libelta (1807-1878), Warszawa-Poznań 1977, s. 207.

${ }^{2}$ List H. Schmitta do K. Libelta z 3 listopada 1868 roku, Biblioteka Jagiellońska [dalej: BJ], Rkp. 6004 III, t. II, k. 183 - Jagiellońska Biblioteka Cyfrowa, http://jbc.bj.uj. edu.pl/publication/396391 [dostęp: 2.07.2017].

${ }^{3}$ Brulion odpowiedzi K. Libelta na list H. Schmitta 11 grudnia [1868 r.], BJ, Rkp. 6004 III, t. II, k. 186v - jak w przypisie 2.

4 „Jaśnie Wielmożny Panie Prezesie. Dowiadujemy się z pism publicznych, że J.W. Pan Prezes przyrzekł wziąć współudział w mających się odbywać we Lwowie publicznych wykładach, a ponieważ Kraków jest na drodze z Berlina do Lwowa, a nadto chodzą pogłoski, że J.W. Pan Prezes zatrzyma się kilka dni w naszym mieście, 
Ostatecznie termin podróży do Galicji ustalono na kwiecień 1869 roku. Co prawda Henryk Schmitt zaręczał, że „wszyscy prawi Polacy powitają z równą serdecznością weterana kresów wielkopolskich walczącego od lat tak wielu słowem i piórem o prawa narodu i nieustającego na chwilę nawet $\mathrm{w}$ tej walce na wyłomie" ${ }^{\prime \prime}$, ale chyba sam nie spodziewał się, jak gorąco Libelt będzie przyjęty we Lwowie. W mieście zawiązał się komitet odpowiedzialny za organizację wizyty filozofa, któremu chciano przede wszystkim dać „możność zapoznania się" z miejscowymi „stosunkami społecznymi i umysłowymi”, a ostatecznie "przyjęcie Libelta przybrało rozmiary uroczystości tak wspaniałej, o jakiej pierwotnie nie myślano"'. Jak donosiła lwowska "Gazeta Narodowa”, witano go jako „uczonego, pisarza i weterana armii polskiej”, jako „prezesa Polskiego Koła poselskiego w sejmie berlińskim”, a "zgotowane dla niego serdeczne przyjęcie oprócz uznania własnych jego wysokich zasług” było „wyrazem łączności naszej narodowej z Wielkopolską"7.

Podróż Karola Libelta przez Galicję z niemal kronikarską dokładnością relacjonowała prasa (m.in. "Gazeta Narodowa”, "Dziennik Lwowski”, „Gazeta Lwowska”, „Dziennik Literacki”, „Czas”, „Kraj”, „Dziennik Poznański"), dlatego dziś można ją wiernie odtworzyć. Cała podróż trwała dziesięć dni, od 9 do 19 kwietnia 1869 roku. W piątkowy wieczór 9 kwietnia Libelt przybył do Krakowa ${ }^{8}$. Następnego dnia uczestniczył w posiedzeniu zarządu Towarzystwa Przyjaciół Oświaty i w spotkaniu u założyciela tegoż towarzystwa i posła Franciszka Trzecieskiego, "gdzie zebrało się liczne grono Krakowian, pragnąc odświeżyć zawiązane z nim dawniej stosunki" ${ }^{\prime \prime}$. Rankiem $\mathrm{w}$ niedzielę 11 kwietnia razem $\mathrm{z}$ Henrykiem Schmittem wyruszył pociagiem do Lwowa, po drodze na dworcach kolejowych witały go „rady miejskie z burmistrzami na czele, ciała nauczycielskie i obywatelstwo" w Tarnowie, Rzeszowie, Jarosławiu i Przemyślu ${ }^{10}$.

radzibyśmy więc skorzystać ze szczęśliwego zdarzenia, jakie się nam nastręcza, zapraszając Go do poświęcenia i dla nas jakiej chwilki, w której byśmy mieli szczęście słyszeć Jego głos wymowny i Jego światły wykład". List A. Baranieckiego do K. Libelta z 9 lutego 1869 roku, BJ, Rkp. 6004 III, t. I, k. 6-7 - Jagiellońska Biblioteka Cyfrowa, http://jbc.bj.uj.edu.pl/publication/396392 [dostęp: 2.07.2017].

${ }^{5}$ List H. Schmitta do K. Libelta z 4 grudnia 1868 roku, BJ, Rkp. 6004 III, t. II, k. 185 - jak w przypisie 2.

${ }^{6}$ W. Hahn, Karol Libelt we Lwowie w roku 1869. Wspomnienie w setna rocznice urodzin, Lwów 1907, s. 6.

${ }^{7}$ Kronika lwowska, "Gazeta Narodowa” 1869, nr 83.

8 Kronika miejscowa i zagraniczna, "Czas” 1869, nr 82.

${ }^{9}$ W. Hahn, op.cit., s. 11.

${ }^{10}$ Wiadomości miejscowe i potoczne, „Dziennik Poznański” 1869, nr 86. 
Według krakowskiego „Czasu” we Lwowie „od tygodnia na ulicy i w salonie, w kasynie i w teatrze o niczym innym, jak tylko o Libelcie była mowa"11, nic więc dziwnego, że w wieczór przyjazdu filozofa na dworcu kolejowym zebrała się liczna publiczność, a „przed dziewiątą peron był tak przepełniony, że trudno było przecisnąć się przez zbite tłumy"12. Upragniony gość przybył pół godziny później, powitany w imieniu lwowian przez Tomasza Rajskiego podziękował ze wzruszeniem za niezwykłe przyjęcie i udał się do Hotelu Europejskiego. W ślad za nim wyruszył urządzony na jego cześć pochód z pochodniami. Warto przytoczyć opis tego niezwykłego marszu:

Pochód wyruszył spod kościoła OO. Bernardynów, skierował się następnie na plac Mariacki przed Hotel Europejski. Wzięły w nim udział młodzież uniwersytecka i technicka, rzemieślnicza (Towarzystwo „Gwiazda”), kupiecka (Koło Młodzieży Handlowej), rozmaite korporacje i towarzystwa, m.in. „Sokół”, mieszczanie, młodzież szkół średnich i nieprzejrzane tłumy publiczności. Cały pochód podzielono na 18 oddziałów; za każdym oddziałem, niosącym lampiony, postępował oddział z pochodniami. Uczestnicy pochodu postępowali $\mathrm{w}$ szeregach po sześciu [...]. Razem z pochodem postępowały dwie muzyki wojskowe [...]; do podniesienia nastroju przyczyniały się $\mathrm{w}$ niemałej mierze pieśni narodowe, wygrywane na przemian przez obie muzyki. Widok, jaki się patrzącym przedstawiał, był wspaniały: cała olbrzymia przestrzeń placu Mariackiego wydawała się jednym morzem ogniowym. Wrażenie dla oka było tym większe, że lampiony były różnokolorowe w każdym oddziale: białe, różowe, liliowe itp., $\mathrm{w}$ ten sposób najrozmaitsze barwy, dobrane umiejętnie, przedstawiały wprost czarujący widok. Samych lampionów było cztery tysiące, niezliczona zaś ilość pochodni ${ }^{13}$.

Sam Libelt pojawił się na balkonie hotelu i „prawie do łez wzruszony [...] podniósł, że tym przyjęciem uczczono nie jego, lecz Wielkopolan, braci naszych za kordonem, że każdy krok na ziemi naszej przekonywa go, iż nie znajduje się u obcych, lecz u swoich, i że ta tak żywo objawiona łączność wszystkich części Polski pozwala spodziewać się, iż części te spoją się kiedyś w jedną całość" ${ }^{14}$. Może dziwić tak owacyjne i w tak niezwykłej oprawie płonących pochodni powitanie zgotowane Karolowi Libeltowi. Miało ono jednak charakter manifestacji narodowej, pokazania

\footnotetext{
${ }^{11}$ Kronika miejscowa i zagraniczna, „Czas” 1869, nr 84.

12 W. Hahn, op.cit., s. 11.

13 Ibidem, s. 12-13.

${ }^{14}$ Kronika miejscowa i zagraniczna, "Czas” 1869, nr 84.
} 
poczucia jedności Polski mimo jej podziału między trzech zaborców, a Libelta widziano właśnie jako wyraziciela zgody, łączności, solidarności narodowej i wspólnej ojczyzny. Redakcja lwowskiego „Dziennika Literackiego" tłumaczyła, iż tak jak niegdyś oddawano hołd zwycięskiemu orężu polskiemu, tak $\mathrm{w}$ czasach zniewolonej Polski należy sławić tych, którzy walczą „bronią wytrwałości i pracy”, a "takim mężem [...], który ogromnymi zasługami okupił sobie prawo do nazwy wodza na polu narodowej pracy - jest Karol Libelt" ${ }^{\prime 15}$.

Kolejne dni spędzone we Lwowie upłynęły filozofowi rzeczywiście bardzo pracowicie - codziennie wykładał, uczestniczył w różnych posiedzeniach, był podejmowany wspaniałymi przyjęciami i honorowany licznymi toastami i mowami. Główną tematykę jego odczytów, trudnych, ale „nadzwyczaj licznie odwiedzanych”, stanowiły zagadnienia astronomiczne (o spektrum optycznym, o kometach i gwiazdach spadających ${ }^{16}$ ), którymi Libelt wówczas szczególnie się interesował, a które wybrał na przedmiot swych wykładów, bo astronomia jego zdaniem „najbardziej podnosi umysł $\mathrm{i}$ jest wzorem harmonii, jaka i w narodzie panować powinna"17. W bankiecie powitalnym 12 kwietnia uczestniczyło ok. 200 gości, przemawiali m.in. Henryk Schmitt, Kornel Ujejski, hr. Leszek Borkowski i ks. Adam Sapieha. W kolejnych dniach obiad na cześć Libelta wydał książę Jerzy Lubomirski, kurator Zakładu Narodowego im. Ossolińskich, a ucztę pożegnalną przygotowali mieszczanie lwowscy. Ponadto Libelt brał udział w walnym zgromadzeniu Towarzystwa Demokratycznego, zaproszony nań przez jego prezesa Franciszka Smolkę. Odwiedził też Stowarzyszenie Czeladzi Rzemieślniczej „Gwiazda”, Koło Towarzyskie Młodzieży Handlowej, Czytelnię Akademicką i Kasyno Mieszczańskie. Przez kilka dni pobytu we Lwowie Libelt był „rozrywany przez wszystkie tutejsze stowarzyszenia, instytucje, przez wielu prywatnych [...]. Nigdzie nie odmówił, wszędzie z równą był uprzejmością i serdecznościa, wszędzie rzucił zdrowe ziarno myśli i uczucia"18.

${ }^{15}$ Karol Libelt we Lwowie, „Dziennik Literacki” 1869, nr 15.

${ }^{16}$ Wykłady te ukazały się drukiem najpierw w "Przeglądzie Polskim” (1868/1869, t. 4), a później w osobnej nadbitce zatytułowanej Analiza spektralna (Kraków 1869). Trwałym śladem po pobycie Libelta w Galicji było ponadto wznowienie jego trzech popularnych rozpraw, wydane nakładem „Czasu” i przygotowane przez Włodzimierza Wilczyńskiego, z którego dochód przeznaczono „na rzecz pomnika dla Adama Mickiewicza, Zygmunta Krasińskiego i Juliusza Słowackiego". K. Libelt, Rozprawy. O odwadze cywilnej, miłości ojczyzny, wychowaniu ludów, Kraków 1869.

17 Karol Libelt we Lwowie, „Dziennik Poznański” 1869, nr 89.

${ }^{18}$ W. Hahn, op.cit., s. 32. Ogólnie oceniając pozytywnie organizację pobytu i serdeczne przyjęcie Libelta we Lwowie, "Gazeta Narodowa” pozwoliła sobie także na 
W piątkowy wczesny poranek 16 kwietnia Karol Libelt, żegnany przez "liczne grono osób”, opuścił gościnne miasto nad Pełtwią i udał się do Krakowa, dokąd dotarł ok. godz. 15.00. Na dworcu „oczekiwało go licznie zebrane grono przyjaciół oraz publiczności"19. Filozof niewiele miał czasu na odpoczynek - podobnie jak we Lwowie czekała go intensywna praca. Po krótkiej wizycie u córki ${ }^{20}$ już wieczorem tego samego dnia przedstawił wykład dotyczący astronomii w Towarzystwie Naukowym na dochód Towarzystwa Akademików Wzajemnej Pomocy, a w sobotę 17 kwietnia w sali Rady Miejskiej o walce pracy z kapitałem na rzecz Muzeum Techniczno-Przemysłowego. Podejmowany był w Resursie Mieszczańskiej, Towarzystwo Naukowe ugościło go obiadem jako prezesa poznańskiego towarzystwa. Wszystkie te uroczyste przyjęcia obfitowały w mowy, wiersze okolicznościowe i toasty wznoszone przez różne osoby na cześć gościa, a Libelt starał się „prawie każdemu mówcy odpowiadać" 21 . Nawet wieczory spędzane w "towarzystwie familijnym”

żartobliwe wytknięcie kilku błędów organizatorom: „Wśród wzniosłych i rozrzewniających wrażeń, jakich doznaliśmy, nie obeszło się i bez materiału do spostrzeżeń weselszej natury [...]. Prawda, że Libelt w ciagu długiej swojej politycznej kariery nie słyszał może nigdy tyle naraz poronionych płodów kunsztu krasomówczego, co u nas w ciągu dni czterech, ale też nie miał może sposobności - oprócz w r. 1848 - widzieć w mieście polskim tyle gorących i swobodnych objawów patriotycznego ducha. Są jednak podrzędne szczegóły przy każdej takiej uroczystości, na które należałoby na przyszłość zwracać więcej uwagi. I tak na przykład komitet urządzający obiad, powinien sobie zawsze przybierać do pomocy jakiego gastronoma, albowiem nie tylko duchem, słowem Bożym i zimną polędwicą żyje człowiek, ale także ugotowanymi na miękko kalafiorami, dobrze utuczonymi indykami itp. Oprócz tego ludzie od czasu nieboszczyka Diogenesa nawykli do różnych jeszcze innych rzeczy, a mianowicie do używania serwet i do odmieniania noży i widelców przy każdej potrawie. Nauka, literatura, sztuki piękne nawet mogą kwitnąć i bez tych zbytków, ale trochę komfortu nie zawadzi im nigdy". Kronika lwowska, "Gazeta Narodowa” 1869, nr 90.

${ }^{19}$ Kronika miejscowa i zagraniczna, "Czas" 1869, nr 87. Zdaniem korespondenta „Dziennika Poznańskiego” powitanie Libelta w Krakowie było „zupełnie zaimprowizowanym", ponieważ - inaczej niż we Lwowie - nie zawiązał się tu żaden komitet organizacyjny. Nieco złośliwie opisywał niechętnych uroczystemu powitaniu Libelta: „Argumenty oponentów były liczne, potężne, niezbite: «Hm, mówił jeden, pan Libelt ma tu przecież córkę, był tyle razy w Krakowie, dlaczegóż mu dziś owację robić?» Inny bał się, że jeżeli zbyt wspaniale przyjmiemy zacnego i zasłużonego, ale w końcu tylko obywatela, to cóż nam zostanie, gdy np. cesarz kiedy przyjedzie?". Karol Libelt w Krakowie, „Dziennik Poznański” 1869, nr 90.

${ }^{20}$ Młodsza córka Libelta - Stanisława - była żoną Józefa Łepkowskiego, profesora Uniwersytetu Jagiellońskiego.

${ }^{21}$ Kronika miejscowa i zagraniczna, "Czas" 1869, nr 88. Na przyjęciach przemowy wygłaszały ważne osobistości życia Krakowa, jak np. Julian Dunajewski jako rektor Uniwersytetu Jagiellońskiego, Maksymilian Machalski jako prezes Resursy 
u córki nie dawały wytchnienia Libeltowi, bo i tam nie brakowało gości, gdyż „mnóstwo osób obojej płci korzystało ze sposobności poznania szanownego gościa"22. Zmęczony filozof zamierzał opuścić Kraków 18 kwietnia, ale zgodził się pozostać dłużej, by jeszcze w niedzielne południe wygłosić publiczny wykład w sali Hotelu Saskiego na rzecz wracających z niewoli rosyjskiej Polaków ${ }^{23}$. Tego też dnia redakcja „Kraju”, zaprosiwszy „wszystkie redakcje pism wychodzących w Krakowie oraz wielu ludzi pióra dała obiad dla Libelta" ${ }^{24}$. Wreszcie w zimny poniedziałkowy poranek 19 kwietnia filozof wyjechał z miasta nad Wisłą: „Zamarzły Kraków rozgrzał się znów i ospały wstał o siódmej, i lepiej pożegnał, jak przywitał. Tłum był na dworcu kolei liczny, kobiet wiele, straż ogniowa w mundurach we dwa szeregi uszykowana". Po kolejnych przemowach i uściskach „,nareszcie przeraźliwy gwizd rozległ się w powietrzu i wśród okrzyków «niech żyje Libelt!», «niech żyje Wielkopolska!» pociąg odjechał" 25 .

Podróż Karola Libelta do Lwowa i Krakowa i serdeczne przyjęcie go przez mieszkańców tych miast były nie tylko szczegółowo relacjonowane w prasie, ale wywarły też niezatarte wrażenie na uczestnikach tych wydarzeń. Inicjator owej podróży, Henryk Schmitt, pisał do Libelta:

To, co się tu [we Lwowie - A.B.] i w Krakowie działo, należało się najsłuszniej Tobie i idei, której jesteś przedstawicielem. [...] Jeżeli przyjęcie, jakiego doznałeś,

Mieszczańskiej, poseł Franciszek Trzecieski, Józef Majer jako prezes Towarzystwa Naukowego czy poeta i geograf Wincenty Pol.

${ }^{22}$ Kronika miejscowa i zagraniczna, „Czas” 1869, nr 89.

${ }^{23} \mathrm{~W}$ gazetach ukazało się sprawozdanie komitetu organizującego zbiórkę i jego „,najczulsze podziękowanie drowi Karolowi Libeltowi za powyższy odczyt w chwili, kiedy poprzednio kilkoma, dzień po dniu mianymi wykładami w różnych przedmiotach i wśród tego odległymi podróżami tak mocno był już znużony" (Kronika miejscowa $i$ zagraniczna, "Czas” 1869, nr 89). Libelt zreszta, o czym także donosiła prasa, zaniemógł po wykładzie, ale „owa chwilowa słabość, która wobec tak olbrzymich trudów choć przestraszyła, nie zdziwiła jednak nikogo" (Karol Libelt w Krakowie, „Dziennik Poznański” 1869, nr 92).

${ }^{24}$ Było to dość rzadkie wydarzenie, zważywszy na silny spór istniejący pomiędzy najważniejszymi krakowskimi dziennikami - „Czasem” i „Krajem”. Relację z obiadu zamieścił m.in. "Czas” (Kronika miejscowa i zagraniczna, „Czas” 1869, nr 89) i „Dziennik Poznański” (O tem i o owem, „Dziennik Poznański” 1869, nr 93).

${ }^{25}$ Karol Libelt w Krakowie, „Dziennik Poznański” 1869, nr 92. Powrót Libelta do Poznania odnotowano w prasie: „Karol Libelt powrócił w poniedziałek wieczorem z wycieczki swej naukowej do Galicji i po krótkim w mieście naszym pobycie udał się do majątku swego w Wagrowieckim”. Wiadomości miejscowe i potoczne, „Dziennik Poznański" 1869, nr 91. 
wolno nazwać tryumfem, patrzyłem z dumą i radością na ten tryumf, ponieważ był to tryumf potęgi ducha $\mathrm{w}$ chwili wżerającego się w społeczność naszą szkaradnego materializmu ${ }^{26}$.

Sam Libelt też głęboko przeżył pobyt w Galicji, odbierając go przede wszystkim jako wyraz zgody i pragnienia wspólnoty narodowej ${ }^{27}$ :

Rzeczywiście, że pobyt mój w Krakowskiem i w Galicji stał się wypadkiem un événement - bom go ni przewidzieć mógł, ani się spodziewać, i taka ogólna manifestacja nie dała się zrobić ani sztucznie wywołać, ale wyjść musiała z natchnienia, które w ważnych chwilach, jakie nadejść maja, a już są jakby w powietrzu, podają naraz instynkt narodu ${ }^{28}$.

W rezultacie wyprawy do Galicji Libelt otrzymał liczne zaszczyty i godności: członkiem honorowym mianowały go lwowskie Towarzystwo Pedagogiczne i Kasyno Mieszczańskie, Towarzystwo Polskie „Kościuszko" w St. Gallen w Szwajcarii oraz Towarzystwo Nauk Ścisłych w Paryżu. Został także protektorem Stowarzyszenia Nauczycielek w Krakowie i opiekunem Biblioteki Polskiej w Rumunii. W 1873 roku Polska Akademia Umiejętności wybrała go na członka, ale wyboru tego na skutek sprzeciwu władz pruskich nie zatwierdził cesarz austriacki ${ }^{29}$.

Podczas swego pobytu w Galicji Karol Libelt kładł duży nacisk na spotkania z uczącą się młodzieżą. Mówił: „młodość, zapał jest najdzielniejszą potęgą życia, rękojmią doli. Czerstwość i siłę mego umysłu, które zachowałem do dziś, zawdzięczam ciągłemu ocieraniu się o ten pierwiastek"30; „na młodzieży polega przyszłość ojczyzny, gdy starsi zejdą już z pola" ${ }^{31}$. We Lwowie to właśnie młodzież przywitała go marszem z pochod-

${ }^{26}$ List H. Schmitta do K. Libelta z 28 kwietnia 1869 roku, BJ, Rkp. 6004 III, t. II, k. 190-190v - jak w przypisie 2 .

${ }^{27}$ Libelt był wzruszony i zaskoczony zgotowanym mu, zwłaszcza we Lwowie, przyjęciem, ale w swoich przemówieniach wielokrotnie zaznaczał: „Uczczeniem mnie tak świetnym nie składacie hołdu mojej osobie, jest ona tylko wyrazem łączności ziem polskich. Przybywam do was ze stron dalekich, sto mil dzieli ojczyznę moją od was, a przecież wiem, że jestem pomiędzy swoimi, pomiędzy braćmi". Cyt. za: I. Kosmowska, Karol Libelt jako działacz polityczny i społeczny, Poznań 1918, s. 49.

${ }^{28}$ List K. Libelta do W. Wilczyńskiego z 9 maja 1869 roku. K. Libelt, Listy, zebrał, oprac. i wstępem poprzedził Z. Grot, Warszawa 1978, s. 504.

${ }^{29}$ Z. Grot, Na drodze działań legalnych, w: Karol Libelt 1807-1875, Warszawa-Poznań 1976, s. 157.

${ }^{30}$ W. Hahn, op.cit., s. 30.

${ }^{31}$ Kronika miejscowa i zagraniczna, „Czas” 1869, nr 88. 
niami $^{32}$, w Krakowie także spotkał się z dowodami uznania z jej strony. W szczególny sposób zakończyła się wizyta filozofa w krakowskiej Czytelni Akademickiej w sobotnie południe 17 kwietnia 1869 roku. Po powitaniu przez przewodniczącego Czytelni i wygłoszeniu mowy przez Libelta zastępca prezesa Towarzystwa Akademików Wzajemnej Pomocy „przemówił kilka słów gorących, prosił o przyjęcie albumu zawierającego podpisy uczniów akademii i techniki, i takowe gościowi wręczył". Wzruszony filozof podziękował: „ten nowy dowód [...] słodką będzie pamiątką dla mnie, a dla dzieci moich dowodem, że ojciec ich sięgnął po to, co jest najwyższym, bo po miłość i sympatię rodaków"33.

Owa szczególna pamiątka podróży naukowej Karola Libelta do Galicji w 1869 roku, dowód uznania studentów krakowskich dla niego, znajduje się dziś w zbiorach Biblioteki Raczyńskich w Poznaniu ${ }^{34}$. Wcześniej, przez lata, przechowywana była pieczołowicie i przekazywana z pokolenia na pokolenie w rodzinie Libelta, o czym świadczy wpis proweniencyjny znajdujący się na wewnętrznej stronie okładki albumu: „Pamiątka rodzinna przechowywana $\mathrm{w}$ domu moich rodziców odebrana $\mathrm{w}$ dniu mych imienin od brata mego Stanisława w prezencie[.] Posiadał ją od mojej matki i ja przekazuję ją synowi memu Edwardowi. / Celina Łepkowska z Libeltów / Bronowice 22 XI [1]942". Synowa Karola Libelta, żona jego syna Pantaleona (1831-1891) - Franciszka Libelt z Żuchowskich (1847-1936) przekazała album swojemu synowi Stanisławowi (1871-1945). Ten podarował go swojej siostrze - Celinie Łepkowskiej z Libeltów (1870-1950), a ta z kolei swemu synowi - Edwardowi Łepkowskiemu (1902-1979). Ostatecznie córka Edwarda - Barbara Russer z Łepkowskich w 2012 roku przekazała tę cenną pamiątkę po swoim prapradziadku Karolu Libelcie do zbiorów Biblioteki Raczyńskich ${ }^{35}$.

Karty z wpisami studentów krakowskich zostały umieszczone w pudełku koloru bordowego o wymiarach 21 x $13 \mathrm{~cm}$. Na jego okładzinach

${ }^{32}$ Dziękując za to niezwykłe powitanie, Libelt mówił: „Światłem przyjęliście mnie, pamiętajcie, że wy powinniście byś światłem narodu! W was, młodzieży, spoczywa przyszłość Polski. Pracujcie, aby ojczyzna nasza zajęła wielkie, dawne, należne jej wśród rzeszy oświeconych narodów miejsce. Niech młoda Polska będzie godną tej, która wydała Kopernika”. Karol Libelt we Lwowie, „Dziennik Poznański” 1869, nr 86.

33 Obszerną relację z tego spotkania i streszczenie mowy Libelta zamieścił „Dziennik Poznański” (Karol Libelt w Krakowie, „Dziennik Poznański” 1869, nr 92).

${ }^{34}$ Sygn. Rkp. 4498, inw. 4498.

35 Podczas wizyty w Poznaniu w 2012 roku państwo Barbara i Aleksander Russer przekazali do zbiorów Biblioteki Raczyńskich także kilkanaście książek autorstwa Karola Libelta, w tym wiele z wpisami własnościowymi Franciszki Libeltowej, synowej filozofa. 
znajdują się pozłacane tłoczenia: w narożnikach motywy roślinne, na okładzinie górnej herb Rzeczpospolitej (polski Orzeł i litewska Pogoń, il. 1), a na okładzinie dolnej godło Uniwersytetu Jagiellońskiego. Na grzbiecie wytłoczono datę: „dnia 17. Kwietnia. 1869 r.”. Wszystkie karty zostały starannie edytorsko przygotowane. Na pierwszej znajduje się tytuł albumu: „JEDNEMU Z NAJZACNIEJSZYCH / KAROLOWI LIBELTOWI / Mężowi pełnemu zasług na każdem polu ojczystych potrzeb / składają tę skromną pamiątkę / KRAKOWSCY AKADEMICY / jako dowód czci niewysłowionej, / którą w sercach swoich IMIĘ JEGO wypisali" (il. 2). Poza stroną tytułową rękopis liczy 58 kart z pozłacanymi brzegami. Każdą kartę otacza ozdobna ramka z motywem ściskających się dłoni, a wewnątrz niej umieszczono $\mathrm{u}$ dołu $\mathrm{w}$ prawym i lewym rogu godło Uniwersytetu Jagiellońskiego, pomiędzy nimi zaś herb Krakowa. Na poszczególnych kartach pozostawiono miejsce na sześć wpisów - po trzy wpisy w każdej kolumnie. Wszystkie miejsca zostały skrzętnie wypełnione podpisami jest ich łącznie $348 \mathrm{w}$ całym rękopisie, z czego indywidualnych nazwisk jest 341, bo siedmiu studentów wpisało się do albumu dwukrotnie. Obok nazwisk wpisujący się podawali określenie kierunku swoich studiów (np. "słuchacz praw", „medyk", "filozof", ,teolog”, ,technik").

Można przypuszczać, iż album powstał ze wspólnej inicjatywy dwóch organizacji studenckich działających wówczas na Uniwersytecie Jagiellońskim - Towarzystwa Akademików Wzajemnej Pomocy ${ }^{36}$ i Czytelni Akademickiej ${ }^{37}$. Dla pierwszej Karol Libelt miał odczyt 16 kwietnia, a w drugiej złożył wizytę dzień później. Wtedy też przedstawiciele obu organizacji wręczyli mu album. Nie wiadomo, jak akademicy zbierali podpisy, być może czynili to podczas swoich zebrań lub karty można było

36 Towarzystwo to powstało w 1866 roku jako pierwsze ogólne stowarzyszenie młodzieży na Uniwersytecie Jagiellońskim. Jego celem było wspieranie przez zapomogi lub pożyczki „potrzebujących, pilnych i prawych uczniów Uniwersytetu” i miało zawsze dużą liczbę członków. Zob. Kronika Uniwersytetu Jagiellońskiego od r. 1864 do r. 1887 i obraz jego stanu dzisiejszego wraz z rzecza o rektorach od czasów najdawniejszych, Kraków 1887, s. 15, 246-247.

37 Prawdopodobnie od 1859 roku istniała jako towarzystwo tajne, jako jawne od 1867 roku. Czytelnia Akademicka miała „ułatwić uczniom Uniwersytetu wyższe i gruntowne wykształcenie we wszystkich gałęziach nauk". Na początku nie zyskała takiego uznania jak Towarzystwo Wzajemnej Pomocy, miała tylko 83 członków i niewielki księgozbiór (w 1866 roku zaledwie 206 dzieł). Dopiero od 1869 roku, kiedy władze akademickie wzięły ją pod swoją opiekę i otrzymała pozwolenie na gromadzenie czasopism literackich i dzienników politycznych, wzrosła jej popularność, co przejawiało się rosnącą liczbą członków, organizacją wielu odczytów, różnych kół zainteresowań i obchodów narodowych rocznic. Zob. Kronika Uniwersytetu Jagiellońskiego..., s. 247-249. 


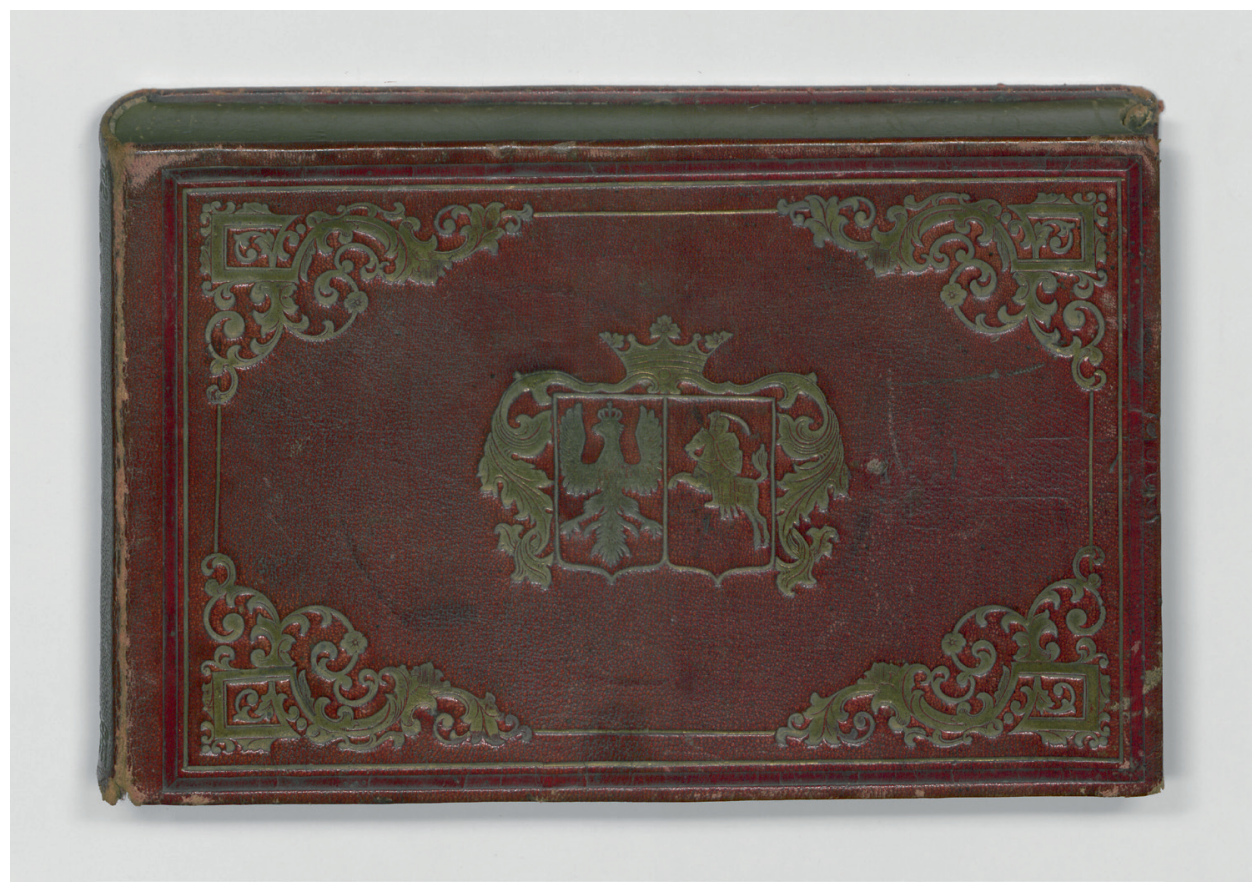

Il. 1. Okładka albumu

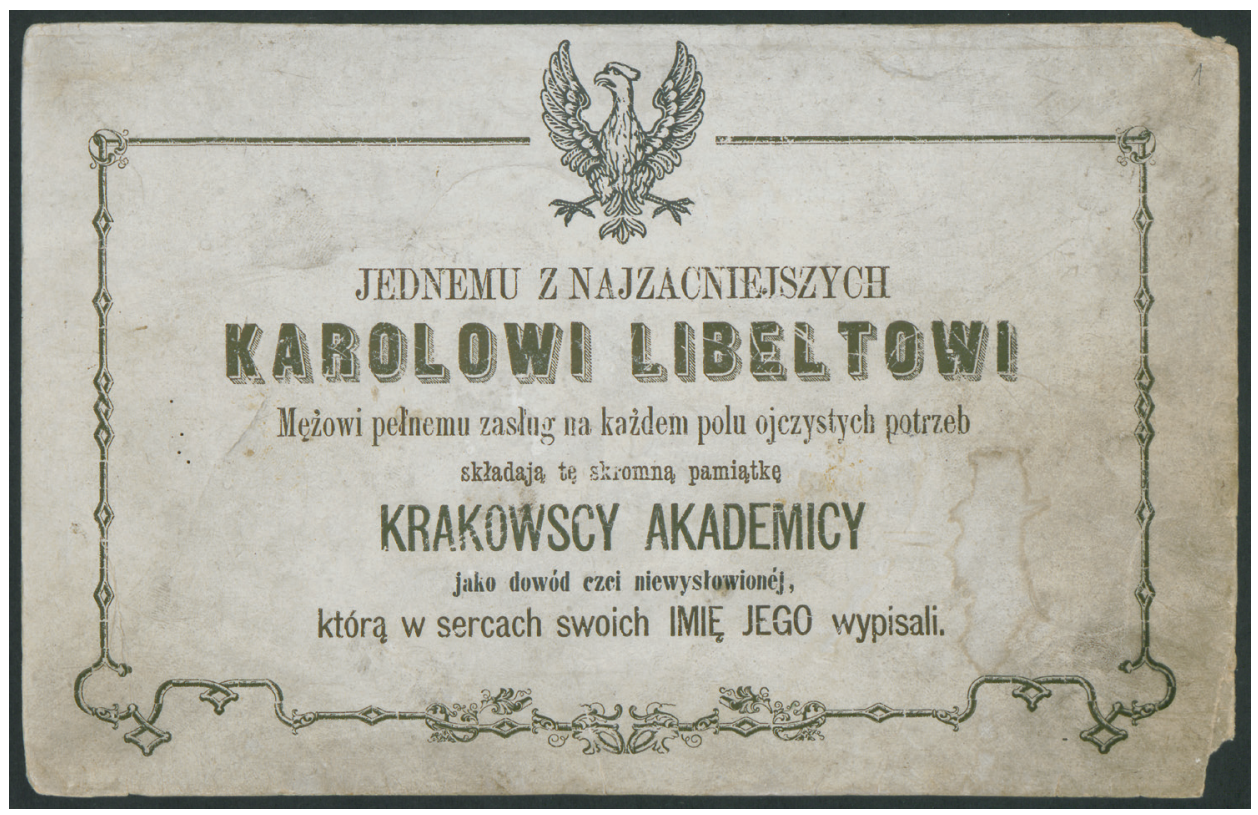

Il. 2. Karta tytułowa albumu 
podpisywać $\mathrm{w}$ ich siedzibach. W każdym razie zebranie blisko 350 podpisów wymagało sprawności organizacyjnej. Swoje nazwiska w albumie umieścili przede wszystkim studenci Uniwersytetu Jagiellońskiego (277) i Instytutu Technicznego (53). Nie wszyscy podpisywali się starannie, ale i tak spośród 341 nazwisk udało się odczytać większość, bo aż 332. W odczytaniu i pierwszym etapie identyfikacji słuchaczy Uniwersytetu Jagiellońskiego nieocenioną pomocą było ukazujące się w latach 1999-2015 ośmiotomowe wydawnictwo Corpus studiosorum Universitatis Iagellonicae 1850/51-1917/1838. Zawiera ono spisy studentów powstałe na podstawie materiałów źródłowych przechowywanych w Archiwum UJ, głównie ankiet wpisowych słuchaczy, własnoręcznie przez nich wypełnianych i składanych w każdym semestrze nauki, oraz wydziałowych i senackich katalogów studentów prowadzonych przez administrację uniwersytetu ${ }^{39}$. W dalszej identyfikacji osób z albumu i próbie rekonstrukcji ich życiorysów przydatne były liczne słowniki biograficzne, na czele z Polskim słownikiem biograficznym, Słownikiem biograficznym adwokatów polskich, Słownikiem lekarzy polskich XIX wieku czy Słownikiem biograficznym techników polskich ${ }^{40}$.

W albumie zdecydowanie przeważa liczba wpisów studentów Uniwersytetu Jagiellońskiego (277 na 332 zidentyfikowane nazwiska), jego czterech głównych wydziałów: Prawa (110), Lekarskiego (76), Filozoficznego (55) i Teologicznego (36). W drugim półroczu roku akademickiego 1868/69 na uniwersytecie studiowało łącznie 446 osób, z czego na wydziałach: Prawa 152, Lekarskim 140, Filozoficznym 80 i Teologicznym $53^{41}$. Do albumu dla Karola Libelta wpisała się zatem więcej niż połowa ówczesnych studentów wszechnicy krakowskiej. Warto jeszcze wspo-

38 Owych osiem tomów jest częścią wydawnictw Archiwum Uniwersytetu Jagiellońskiego, seria C: Corpus studiosorum Universitatis Iagellonicae in saeculis XVIII-XX, t. 3 i obejmuje informacje o studentach z lat 1850-1918. Zob. Corpus studiosorum Universitatis Iagellonicae 1850/51-1917/18 [dalej: Corpus...], A-D, red. J. Michalewicz, Kraków 1999; Corpus..., E-J, red. K. Stopka, Kraków 2006; Corpus..., K-モ, red. K. Stopka, Kraków 2009; Corpus..., M-N, red. K. Stopka, Kraków 2011; Corpus..., O-Q, red. K. Stopka, Kraków 2011; Corpus..., R, red. K. Stopka, Kraków 2013; Corpus..., S-Ś, red. K. Stopka, Kraków 2014; Corpus..., T-Ż, red. K. Stopka, Kraków 2015.

${ }^{39}$ Corpus..., A-D, s. VIII-IX.

40 Polski słownik biograficzny [dalej: PSB], t. I-LI/2, Kraków-Wrocław-Warszawa 1935-2016; Słownik biograficzny adwokatów polskich, t. 1, z. 1-5, Warszawa 1980-1985, t. 2, z. 1-4, Warszawa 1988-2007; P. Szarejko, Słownik lekarzy polskich XIX wieku [dalej: Słownik lekarzy], t. 1-6, Warszawa 1991-2001; Słownik biograficzny techników polskich, z. 1-24, Warszawa 1989-2013.

${ }^{41}$ Ponadto w Wykazie statystycznym uczniów Uniwersytetu Jagiellońskiego w osobnej rubryce wymieniono farmaceutów (w drugim półroczu 1868/69 było ich 21). Zob. Kronika Uniwersytetu Jagiellońskiego..., s. 244. 


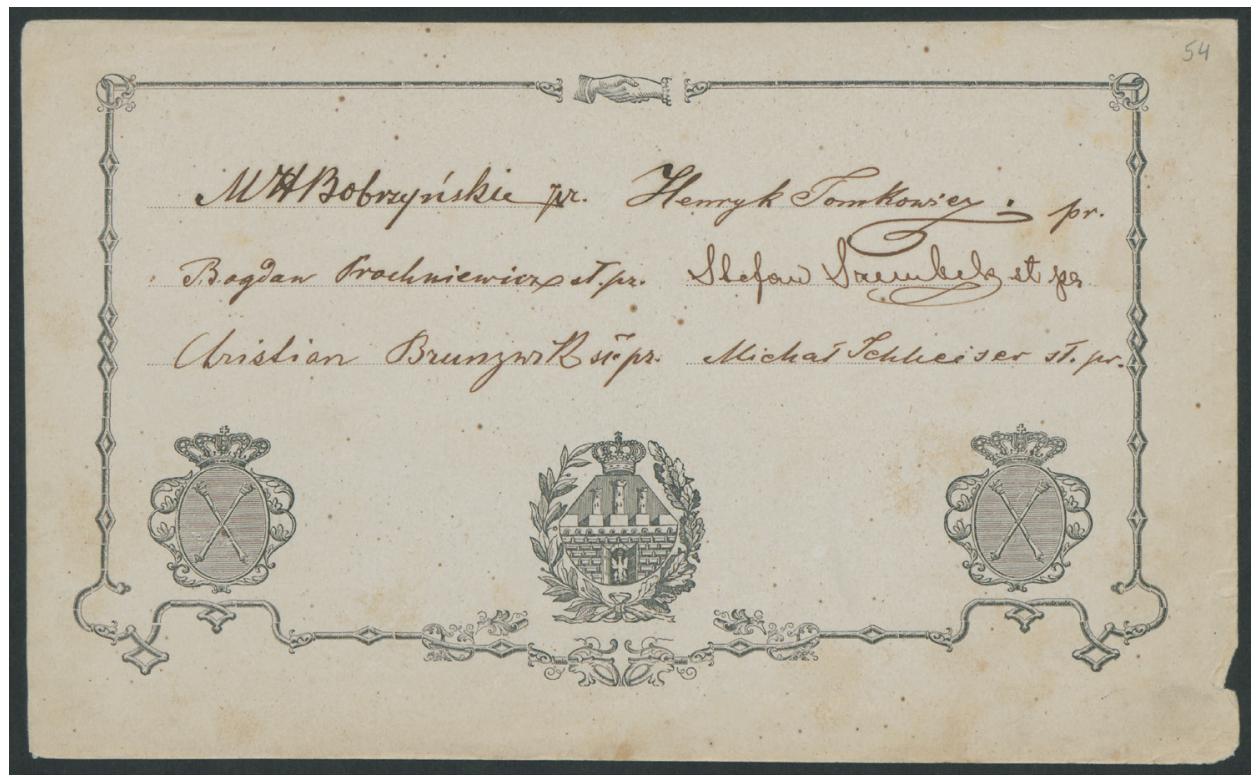

Il. 3. Karta z podpisem Michała Hieronima Bobrzyńskiego (1849-1935)

mnieć, że rok 1869 był bardzo istotny w jej dziejach. Wcześniej, w latach 1853-1860 była pozbawiona autonomii i systematycznie germanizowana, następnie kilka lat trwała walka o repolonizację uczelni, zakończona ostatecznie w 1870 roku całkowitym uznaniem przez władze austriackie języka polskiego jako wykładowego. W 1869 roku kończył się zatem proces repolonizacji uniwersytetu i powoli zaczynał nowy etap, oznaczający szybki jego rozwój organizacyjny i naukowy oraz wzrost jego społeczno-politycznej roli ${ }^{42}$. Bez wątpienia kilku spośród studentów wpisujących się w 1869 roku do albumu dla Karola Libelta przyczyniło się do przywrócenia świetności krakowskiej Alma Mater.

Najliczniej w albumie reprezentowani są studenci Wydziału Prawa Uniwersytetu Jagiellońskiego, których wpisało się aż 110. Zwykle po swoim nazwisku podawali określenie „prawnik” lub "słuchacz praw”.

Bez wątpienia jednym $\mathrm{z}$ cenniejszych autografów w albumie Libelta jest ten należący do Michała Hieronima Bobrzyńskiego (1849-1935), w latach 1867/68-1870/71 studenta Uniwersytetu Jagiellońskiego, a od 1879 roku już profesora zwyczajnego prawa polskiego i niemieckiego tej uczelni (il. 3). Uważany dziś za jednego z najwybitniejszych historyków

${ }^{42}$ Więcej o dziejach uczelni w XIX wieku - zob. A.K. Banach, Czasy zaborów. Uniwersytet Jagielloński w latach 1795-1918, w: K. Stopka, A.K. Banach, J. Dybiec, Dzieje Uniwersytetu Jagiellońskiego, Kraków 2000, s. 85-162. 
polskich, był wraz z Józefem Szujskim i Walerianem Kalinką współtwórcą krakowskiej szkoły historycznej. Zajmował się głównie politycznymi dziejami Polski. Spośród wielu jego prac wymienić trzeba wartościowa, kilkukrotnie wznawianą syntezę Dzieje Polski w zarysie (1879), rozprawę Nasi historycy wobec wojny światowej (1920) czy obszerne dzieło z historii najnowszej Wskrzeszenie państwa polskiego (t. 1-2, 1922). Aktywną pracę naukową i dydaktyczną (do jego uczniów zaliczali się Oswald Balzer i Stanisław Estreicher) łączył z powodzeniem z działalnością polityczną - był członkiem Rady Miejskiej w Krakowie, wieloletnim posłem na Sejm Krajowy galicyjski, członkiem Rady Państwa w Wiedniu, jednym z przywódców grupy stańczyków w Kole Polskim, wreszcie w latach 1908-1913 pełnił urząd namiestnika Galicji. W 1919 roku wycofał się z życia politycznego i zamieszkał w Wielkopolsce, z którą związany był przez żonę - Zofię, córkę Hipolita Cegielskiego ${ }^{43}$.

Także wielu innych absolwentów Wydziału Prawa z albumu dla Karola Libelta z powodzeniem realizowało karierę polityczną. Zapewne niejednokrotnie z Michałem Bobrzyńskim w stronnictwie stańczyków w sejmie galicyjskim współpracował Adam Jędrzejowicz (1847-1924), ziemianin, pracujący najpierw w administracji rządowej, od 1883 roku związany z polityką. Był wieloletnim posłem do sejmu, do Rady Państwa w Wiedniu (od 1890), wiceprezesem Koła Polskiego (od 1894) i przez krótki czas ministrem dla Galicji (1898-1899). Po wojnie został wiceprezesem Stronnictwa Prawicy Narodowej i członkiem komitetu redakcyjnego "Czasu"44. Z kolei przeciwnikiem politycznym Michała Bobrzyńskiego był Stanisław Stadnicki (1848-1915), ziemianin, od 1882 roku poseł na Sejm Krajowy galicyjski, dożywotni członek austriackiej Izby Panów. Należał do stronnictwa tzw. podolaków, konserwatywnych ziemian z Podola austriackiego, ostro krytykujących Bobrzyńskiego m.in. za jego politykę ukraińską. Stadnicki działał $\mathrm{w}$ galicyjskich towarzystwach ziemiańskich, m.in. gospodarskim i łowieckim. Jeszcze zanim rozpoczął służbę parlamentarną, w swoim majątku Krysowice w 1880 roku gościł cesarza Franciszka Józefa, wizytującego manewry wojskowe w okolicy ${ }^{45}$. Spraw rolnictwa galicyjskiego w Sejmie Krajowym bronił Marian Dydyński (1843-1920), właściciel Raciborska k. Wieliczki, poseł od 1877 roku, od 1895 roku

${ }^{43}$ Rkp. 4498, k. 54; Corpus..., A-D, s. 326-327; PSB, t. II, s. 165-168; Stownik historyków polskich, Warszawa 1994, s. 47-49; Biogramy uczonych polskich, cz. 1: Nauki społeczne, z. 1: A-J, Wrocław 1983, s. 136-142.

${ }^{44}$ Rkp. 4498, k. 32; Corpus..., E-J, s. 1056; PSB, t. XI, s. 238-239; Śmierć śp. Adama Jędrzejowicza, „Czas” 1924, nr 103.

45 Rkp. 4498, k. 29; Corpus..., S-Ś, s. 494; PSB, t. XLI, s. 436-439. 
członek Izby Panów w Wiedniu. Dydyński był prezesem Okręgowego Towarzystwa Rolniczego w Wieliczce i mianowanym przez ministerstwo wyznań i oświaty w Wiedniu konserwatorem w Centralnej Komisji dla Badań i Konserwacji Pomników Sztuki i Historii (jako wielbiciel historii zgromadził we dworze w Raciborsku znaczący księgozbiór, organizował też na własny koszt wykopaliska) ${ }^{46}$. W latach 1901-1914 posłem do Sejmu Krajowego i Rady Państwa był Michał Garapich von Sichelburg (1850-1917), właściciel dóbr, bardziej jednak znany ze swojej działalności społecznej, m.in. jako wieloletni dyrektor Towarzystwa Wzajemnych Ubezpieczeń w Krakowie ${ }^{47}$.

Polityczną działalność z praktyką adwokacką łączył Stanisław Łazarski (1849-1938), poseł do Sejmu Krajowego (1901-1907, 1911-1914) i do Rady Państwa w Wiedniu (1907-1918), prezes Koła Polskiego. Od 1880 roku prowadził własną kancelarię, aktywnie działał w środowisku prawniczym, a jako adwokat cieszył się dużą popularnością zwłaszcza po głośnym procesie (w 1908 roku w Wadowicach) Wandy Krahelskiej, działaczki Polskiej Partii Socjalistycznej, oskarżonej o dokonanie zamachu na generała-gubernatora warszawskiego Gieorgija Skałona. Szeroko komentowano wówczas jego słowa z mowy obrończej: „etyka narodu uciskanego nakazuje z bronią w ręku upomnieć się o swoje prawa"48.

Interesującą postacią z kart rękopisu dla Karola Libelta był Jerzy Moszyński (1847-1924), ziemianin, który w swoim majątku Łoniów zakładał kasy spółdzielcze, ale był przeciwny wszelkiej samodzielnej aktywności chłopów. Ze względu na skrajność poglądów i trudny charakter nie mógł znaleźć partnerów w środowisku politycznym - mówiono o nim, że stanowi ,jednoosobowe stronnictwo". Jako płodny publicysta, uprawiający namiętnie "politykę prywatną", ogłosił wiele rozpraw polemicznych i listów w obronie zasad konserwatywno-klerykalnych, własnym nakładem wydał ponad 100 książek $^{49}$.

Niektóre z wpisów w albumie z 1869 roku należą do późniejszych adwokatów aktywnie włączających się w życie miast, w których prowadzili praktykę zawodową. Najlepszym przykładem jest Karol Pieniążek (1850-1900), ceniony w środowisku adwokackim w Krakowie,

${ }^{46}$ Rkp. 4498, k. 14; Corpus..., A-D, s. 901; PSB, t. VI, s. 48; Śp. Maryan Dydyński, „Czas" 1920, nr 103; Marian Dydyński-dziedzic Raciborska, http://www.kozmice.pl/47. html\#dydynski [dostęp: 6.07.2017].

${ }^{47}$ Rkp. 4498, k. 31; Corpus..., E-J, s. 264; „Kurier kolejowy i asekuracyjny” 1911, nr 11, s. 7; Kronika, „Gazeta Lwowska” 1917, nr 50, s. 4.

${ }^{48}$ Rkp. 4498, k. 44; Corpus..., K-E, s. 1075; PSB, t. XVIII, s. 291; Stanisław Eazarski, „Ilustrowany Kuryer Codzienny" 1938, nr 323, s. 7.

49 Rkp. 4498, k. 6; Corpus..., M-N, s. 545; PSB, t. XXII, s. 119-120. 
gdzie w 1879 roku otworzył własną kancelarię. Poza pracą zawodową aktywnie działał w samorządzie miejskim Krakowa, w Radzie Miasta zasiadał od 1884 roku do końca życia (był m.in. wiceprezydentem miasta, przewodniczącym sekcji prawniczej Rady Miejskiej, rzecznikiem spraw rzemieślniczych, członkiem komisji gazowej, statutowej, wodociągowej, konsensowej oraz komitetu muzealnego). Jako prawnik opiniował i opracowywał wiele umów i zapisów na rzecz miasta ${ }^{50}$. Radcą magistratu krakowskiego, samodzielnym referentem do spraw dobroczynności (od 1890 roku) i członkiem komisji statystycznej, a ponadto obrońcą w sprawach karnych był Jan Ludwik Turnau (1844-1899). Do dziś w Krakowie na skrzyżowaniu ulic Łobzowej i Siemiradzkiego podziwiać można piękną, okazałą kamienicę, wybudowaną w 1890 roku przez znanego architekta Jana Zawiejskiego, której Turnau był właścicielem ${ }^{51}$. Z kolei Franciszek Doliński (1850-1914) po studiach na Uniwersytecie Jagiellońskim osiadł w Przemyślu. Otworzył tam własną kancelarię adwokacka, działał aktywnie $\mathrm{w}$ różnych organizacjach, przez wiele lat był radnym miejskim, a w latach 1901-1914 burmistrzem Przemyśla ${ }^{52}$.

W wyuczonym zawodzie pracowało wielu słuchaczy Wydziału Prawa Uniwersytetu Jagiellońskiego wpisanych do albumu dla Karola Libelta. Julian Morelowski (1850-1916) był doktorem prawa, prokuratorem, w latach 1906-1912 radcą dworu przy Sądzie Najwyższym w Wiedniu, a ponadto autorem wielu prac naukowych i popularnonaukowych, głównie z dziedziny prawa karnego ${ }^{53}$. Wincenty Tarłowski (1848-1922) rozpoczynał karierę jako adiunkt w Wadowicach. W 1887 roku został zastępcą prokuratora państwa w Krakowie, a w 1899 roku cesarz mianował go radcą dworu przy Najwyższym Trybunale Sądowym i Kasacyjnym w Wiedniu. W 1907 roku Tarłowski otrzymał tytuł prezydenta senatu Sądu Najwyższego ${ }^{54}$.

${ }^{50}$ Rkp. 4498, k. 6; Corpus..., O-Q, s. 357-358; PSB, t. XXVI, s. 99-100; Stownik biograficzny adwokatów polskich. M-R, t. 1, Warszawa 1982, s. 327-328; Karol Pieniążek, "Czas" 1900, nr 305, s. 3.

${ }^{51}$ Rkp. 4498, k. 32; Corpus..., T-Ż, s. 178; 12 VI 1890: Kamienica Jana i Karoliny Turnau'ów w Krakowie, http://kalendariumdawnejprasy.blogspot.com/2014/06/12-vi-1890-kamienica-jana-i-karoliny.html [dostęp: 7.07.2017].

52 Rkp. 4498, k. 44; Corpus..., A-D, s. 813; T. Pudłocki, Burmistrz Franciszek Doliński - mistrz zręcznej polityki, "Nasz Przemyśl” 2009, nr 8, s. 41; Dr Franciszek Doliński, „Głos Rzeszowski” 1914, nr 7, s. 5.

${ }^{53}$ Rkp. 4498, k. 19; Corpus..., M-N, s. 519; PSB, t. XXI, s. 766-767; D. Janicka, O pionierach nauk kryminologicznych w Polsce, "Czasopismo Prawno-Historyczne" 2016, t. 68 , s. 1 , s. 44 .

${ }^{54}$ Rkp. 4498, k. 10; Corpus..., T-Ż, s. 27; T.J. Kotliński, Poczet sędziów krakowskich, cz. XXXIII, „Krakowskie Zeszyty Sądowe”, R. XXVI, 2016, nr 1 (301), s. 52-53. 


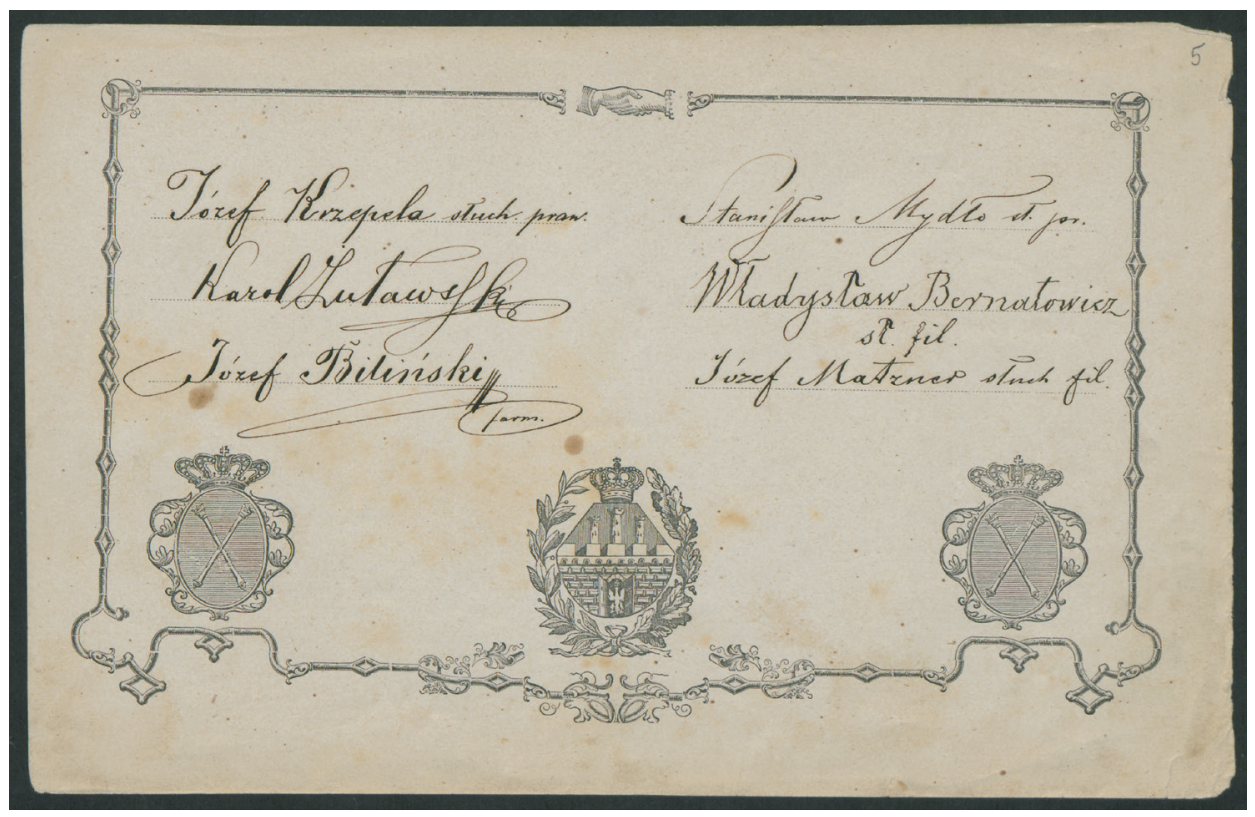

Il. 4. Karta z podpisami Józefa Krzepeli (1846-1935) i Karola Żuławskiego (1845-1914)

Ludwik Misky (1847-1915) praktykował w sądownictwie krajowym, pracował m.in. w Nowym Sączu i Limanowej, był radcą w Sądzie Obwodowym w Wadowicach (1893-1899) i radcą apelacyjnym ${ }^{55}$. Adwokatem krajowym, wiceprezydentem rady dyscyplinarnej krakowskiej Izby Adwokackiej i radcą miejskim był z kolei Michał Ichheiser (1849-1911) ${ }^{56}$.

Inni studenci Wydziału Prawa co prawda pracowali w zawodzie, ale w słownikach biograficznych zapisali się z innych względów. Na przykład Józef Krzepela (1846-1935) był sędzią sądu apelacyjnego w Krakowie, a poza tym z powodzeniem zajmował się heraldyką i genealogia, prowadząc badania nad rozsiedleniem szlachty na ziemiach polskich (il. 4). Jest autorem do dziś wykorzystywanych prac, by wspomnieć tylko Rody ziem pruskich (1927), Małopolskie rody ziemiańskie (1928) czy Rody ziemiańskie XV i XVI w.57. W krakowskim Gimnazjum św. Anny, a następnie na Uniwersytecie Jagiellońskim Krzepela na pewno spotykał Jana

${ }^{55}$ Rkp. 4498, k. 30; Corpus..., M-N, s. 457; T.J. Kotliński, Sąd Obwodowy w Wadowicach. Jego prezydenci i radcy (1882-1899), „Wadoviana. Przegląd historyczno-kulturalny" 2015, nr 18, s. 36.

${ }^{56}$ Rkp. 4498, k. 54; Corpus..., E-J, s. 862-863; Zmarli. Dr Michał Ichheiser, „Nowa Reforma" 1911, nr 130.

${ }^{57}$ Rkp. 4498, k. 5; Corpus..., K-モ, s. 665; Stownik historyków polskich..., s. 47-49. 


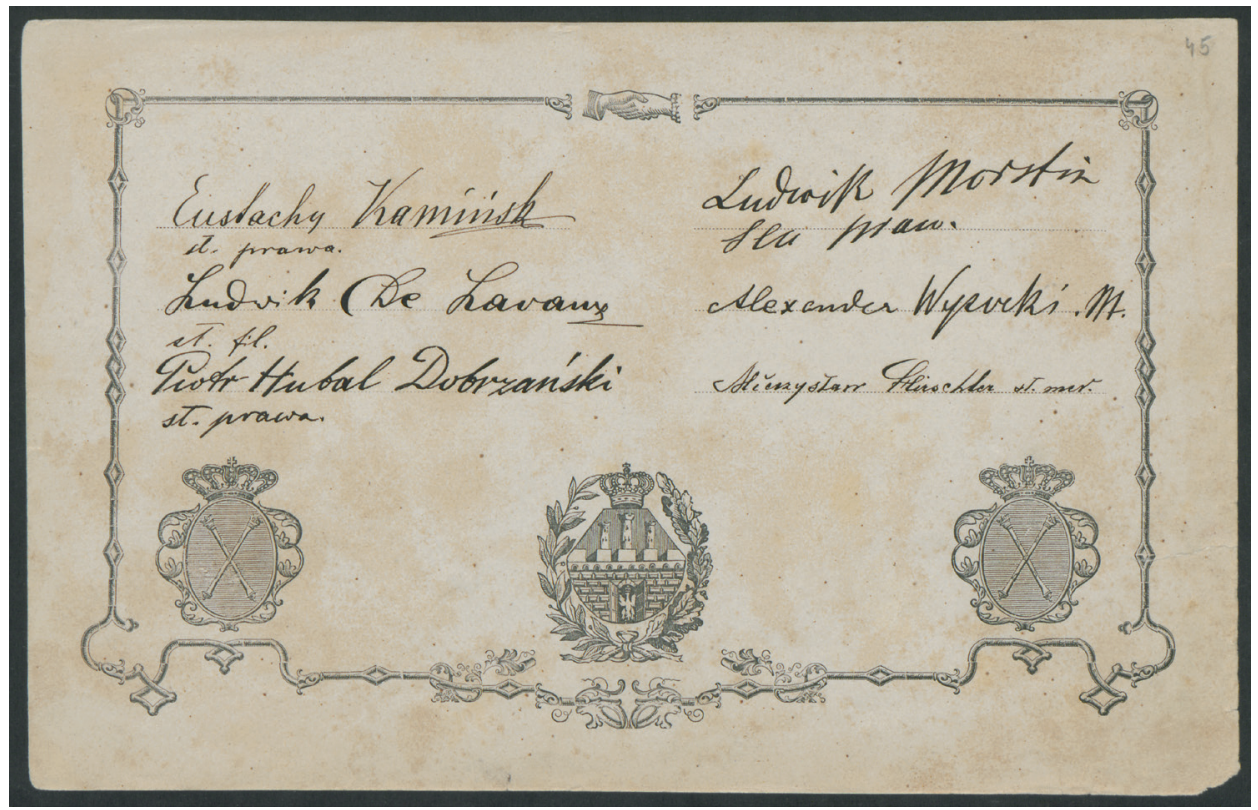

Il. 5. Karta z podpisem Piotra Hubala Dobrzańskiego (1845-1925)

Sitowskiego (1846-1922), który po studiach pracował m.in. jako sędzia grodzki w Krościenku i radca sądowy w Nowym Sączu. Na emeryturze zamieszkał w swoim dworze w Mordarce k. Limanowej. Poświęcił się tam pisaniu broszur z poradami prawniczymi i weterynaryjnymi (np. Pogadanka o chorobach $i$ wadach zwierzat domowych, 1912) oraz wspomnień i opracowań dotyczących regionu Sądecczyzny i ziemi limanowskiej (m.in. Wspomnienia limanowskie i starosadeckie z 1916, Dwory i dworki w Limanowszczyźnie oraz ich właściciele w ostatnich dziesiątkach XIX w. z 1918) ${ }^{58}$. Interesujący jest też wpis Piotra Hubala Dobrzańskiego (1845-1925, il. 5), który po studiach uniwersyteckich w Wiedniu i Krakowie w 1871 roku uzyskał tytuł doktora praw, ale specjalnej kariery prawniczej nie zrobił (pracował m.in. w cesarsko-królewskim namiestnictwie i starostwach w Krakowie, Myślenicach i Tarnowie). Do historii przeszedł natomiast jako opiekun, powiernik i wieloletni przyjaciel Jacka Malczewskiego. To właśnie Dobrzański w 1872 roku przedstawił jego prace Janowi Matejce, co miało przełomowe znaczenie w życiu młodego artysty. Dobrzański,

${ }^{58}$ Rkp. 4498, k. 47; Corpus..., S-Ś, s. 273; M. Kowalska, Właściciele dworu w Mordarce, "Almanach Sądecki”, R. VII, 1998, nr 3 (24), s. 18-20. Warto dodać, że syn Jana Sitowskiego - Ludwik (1880-1947), zoolog i entomolog, był profesorem i rektorem Uniwersytetu Poznańskiego (zob. PSB, t. XXXVII, s. 589-592). 
obok ojca i Adolfa Dygasińskiego, miał największy wpływ na losy artystyczne Malczewskiego, przez wiele lat wspierał go także materialnie, a jego rysy zostały utrwalone $\mathrm{w}$ niejednym obrazie tego wybitnego malarza ${ }^{59}$.

Niektóre osoby z albumu dla Libelta miały w swojej biografii bardziej lub mniej znaczący epizod związany z powstaniem styczniowym. Na przykład Ignacy Ślebodziński (1847-1921) w czasie tego powstania, gdy uczył się w gimnazjum w Rzeszowie, został oskarżony o przynależność do konspiracji niepodległościowej i osadzony w areszcie w Krakowie. Ślebodziński powstaniu poświęcił broszurę Niedokończony dramat dziejowy. Po studiach pracował jako sędzia, m.in. w Rozwadowie, a ostatnie lata życia spędził w Gnieźnie ${ }^{60}$.

Spośród wpisów osób, które przy swoim nazwisku dopisały „słuchacz praw", a jednak w życiu zawodowym poszły zupełnie inną drogą, warto zwrócić uwagę na jeszcze jeden podpis. Otóż Wiktor Klobassa Zręcki (1849-1896) po studiach prawniczych w Krakowie i w Wiedniu wyjechał do Stanów Zjednoczonych Ameryki Północnej, by zapoznać się z tamtejszym przemysłem naftowym. Zdobyte tam doświadczenie wykorzystał po powrocie do kraju w 1881 roku, wchodząc m.in. do zarządu Krajowego Towarzystwa Naftowego i Krajowej Rady Górniczej. Po śmierci ojca odziedziczył część dobrze prosperującej kopalni w Bóbrce, a dzięki współpracy z zagranicznymi inwestorami propagującymi nowy system wierceń, bardzo efektywny w polskich warunkach geologicznych, stał się współwłaścicielem innych kopalń. Klobassa Zręcki, choć z wykształcenia prawnik, został znakomitym przedsiębiorcą i przyczynił się do ożywienia przemysłu naftowego w zachodniej Galicji ${ }^{61}$.

Słuchacze Wydziału Lekarskiego Uniwersytetu Jagiellońskiego, których w albumie wpisało się 76, obok swojego nazwiska najczęściej podawali hasło „medyk". Spośród ich autografów w rękopisie bardzo cenny

${ }^{59}$ Rkp. 4498, k. 45. Corpus..., A-D, s. 806; J. Puciata-Pawłowska, Jacek Malczewski, Wrocław 1968, s. 15 i n.; Z korespondencji Jacka Malczewskiego. Listy Jacka Malczewskiego do Piotra Hubala Dobrzańskiego, oprac. D. Kudelska, „Rocznik Historii Sztuki” 1990, t. 18, s. 259-290; Z.K. Posiadała, Śladami Jacka Malczewskiego, Radom 2012; J. Lombarski, Piotr Hubal Dobrzański, przyjaciel Jacka Malczewskiego, „Gazeta Radomska” 2016, nr 1, s. 12.

${ }^{60}$ Rkp. 4498, k. 43; Corpus..., S-Ś, s. 915; Niedokończony dramat dziejowy. Odczytał w dniu 24-tym stycznia 1909 na wieczorku urzadzonym ku pamięci styczniowego powstania [broszura], (Cieszyn, s.a.) wraz z biogramem I. Ślebodzińskiego opracowanym przez A.B. Ślebodzińskiego: https://get.google.com/albumarchive/106561962250549489911/ album/AF1QipO8xRsjYG_2gtoY7tE-NuSWPeNLrGm2Kpfuwhx9 [dostęp: 7.07.2017].

${ }^{61}$ Rkp. 4498, k. 43; Corpus..., K-E, s. 247; PSB, t. XIII, s. 1-2. 


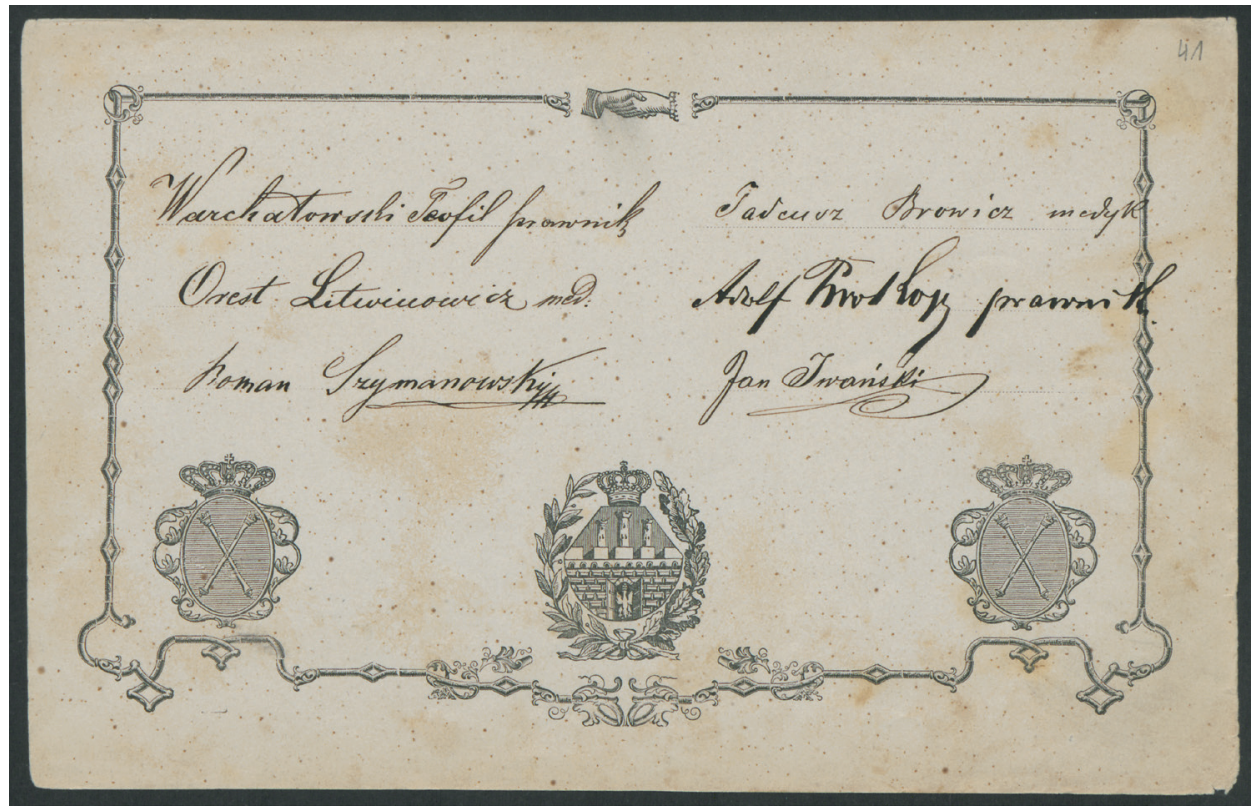

Il. 6. Karta z podpisem Tadeusza Browicza (1847-1928)

jest ten złożony ręką Tadeusza Browicza (1847-1928, il. 6), jednego z wybitniejszych uczonych polskich przełomu XIX i XX wieku, który ukończył studia z tytułem doktorskim w 1873 roku. W latach 1876-1919 był profesorem anatomii patologicznej na Uniwersytecie Jagiellońskim (od 1882 roku profesorem zwyczajnym), piastował także stanowisko dziekana Wydziału Lekarskiego, a w latach 1894-1895 rektora uniwersytetu. Do jego największych osiągnięć należało odkrycie pałeczki duru brzusznego (1874) i opisanie (przed niemieckim anatomem Karolem Kupfferem) komórek gwiaździstych układu siateczkowo-śródbłonkowego w naczyniach krwionośnych wątroby (1898), nazywanych dziś w literaturze fachowej komórkami Browicza-Kupffera. Był członkiem wielu organizacji, m.in. Akademii Umiejętności i Towarzystwa Lekarskiego Krakowskiego, współzałożycielem Towarzystwa Higienicznego Krakowa i autorem Słownika lekarskiego polskiego $(1905)^{62}$. Ginekologiem i położnikiem był Władysław Bylicki (1846-1931). Pracę naukowa, najpierw na Uniwersytecie Jagiellońskim, a później we Lwowie, łączył z praktyką lekarską. Zasłynął jako autor starannie wydanego, doskonale opracowanego i świetnie w środowisku naukowym przyjętego podręcznika Nauka o chorobach

${ }^{62}$ Rkp. 4498, k. 41; Corpus..., A-D, s. 430; PSB, t. II, s. 475-476; M. Ciszyńska, Tadeusz Browicz (1847-1928), „Medyk Białostocki” 2010, nr 84, s. 17-18. 
kobiecych (ginekologia), opublikowanego w 1894 roku (dziś stanowiącego rzadkość bibliofilską), oraz konstruktor miednicomierza, tzw. cyrkla Bylickiego. Był członkiem Polskiej Akademii Umiejętności, aktywnym działaczem wielu towarzystw fachowych (m.in. Lwowskiego Towarzystwa Lekarskiego, Towarzystwa Ginekologicznego Lwowskiego), zasłużył się jako organizator zjazdów lekarzy i przyrodników polskich ${ }^{63}$. Jako wybitny pediatra na kartach historii medycyny polskiej zapisał się Emil Merczyński (1845-1907), w latach 1877-1900 dyrektor Szpitala dla Dzieci im. św. Zofii we Lwowie. We wspomnieniu pośmiertnym jego asystent dr Stanisław Czarnik pisał: „Ten pierwszy szpital dla dzieci we wschodniej Galicji powstał w znacznej części - jako dzieło ludzi dobrej woli - za staraniem ś.p. Merczyńskiego i tej to instytucji poświęcił Zmarły pracę całego swego życia, oddając się z zamiłowaniem chorym dzieciom w szpitalu i poza szpitalem". Merczyński założył także kolonię leczniczą dla dzieci w Rymanowie i Iwoniczu, opublikował liczne prace $\mathrm{z}$ dziedziny pediatrii, był wykładowcą Uniwersytetu we Lwowie i członkiem wielu towarzystw lekarskich ${ }^{64}$. W dziejach psychiatrii polskiej zapisał się z kolei Karol Zuławski (1845-1914, il. 4), który w 1870 roku uzyskał tytuł doktora wszech nauk lekarskich, a w 1897 roku został mianowany profesorem tytularnym psychiatrii Uniwersytetu Jagiellońskiego. Pracował w „Oddziale obłąkanych, epileptyków i pokąsanych przez psy wściekłe" najpierw w Szpitalu św. Ducha, a później św. Łazarza. Był członkiem Towarzystwa Lekarskiego Krakowskiego i właścicielem prywatnej lecznicy - „Domu zdrowia dla umysłowo chorych", z której usług korzystali m.in. żona Jana Matejki Teodora i Stanisław Wyspiański ${ }^{65}$.

Kilku spośród studentów Wydziału Lekarskiego z albumu dla Libelta zostało lekarzami zdrojowymi. Największy sukces odniósł Józef Kołączkowski (rodowe nazwisko Wiercioch, 1842-1925). Od ukończeniu studiów w 1874 roku praktykował w Nowym Sączu (m.in. jako naczelny lekarz szpitala) i od 1881 roku w Szczawnicy jako lekarz zdrojowy. W czasie podróży do Niemiec, Szwajcarii, Austrii i Włoch zapoznawał się z fizjoterapeutycznymi metodami leczenia i sposobami prowadzenia pensjonatów. Kiedy osiadł na stałe w Szczawnicy, został właścicielem tamtejszego sanatorium i zakładu wodoleczniczego „Hydropatia”,

${ }^{63}$ Rkp. 4498, k. 20; Corpus..., A-D, s. 507; PSB, t. III, s. 170; Słownik lekarzy, t. 3, s. $66-68$.

${ }^{64}$ Rkp. 4498, k. 48; Corpus..., M-N, s. 305; Słownik lekarzy, t. 3, s. 291-292; S. Czarnik, Ś.p. Emil Merczyński, „Lwowski Tygodnik Lekarski” 1908, nr 12, s. 160.

65 Rkp. 4498, k. 5; Corpus..., T-Ż, s. 965; Słownik lekarzy, t. 3, s. 411-413; G. Herczyńska, Karol Szeliga Żuławski 1845-1914, „Postępy Psychiatrii i Neurologii” 2001, z. 4 (na okładce). 
które cieszyły się dużą frekwencją pensjonariuszy i sławą najnowocześniejszych w kraju ${ }^{66}$. Do albumu wpisali się także dwaj bracia Dębiccy. Starszy, Karol (1845-1901) po ukończeniu studiów praktykował najpierw w Odessie i Petersburgu, a później we Lwowie i Samborze. Ogłaszał się jako lekarz ordynujący w sezonach letnich od 1881 do 1900 roku we Franzensbadzie (Franciške Lázny), gdzie cieszył się uznaniem przebywających tam na kuracji Polaków ${ }^{67}$. Balneologiem był jego młodszy brat Klemens (1846-1928) pracujący jako naczelny lekarz uzdrowiska w Iwoniczu (co roku publikował obszerne broszury na temat właściwości leczniczych, ruchu chorych i leczonych tam chorób), a następnie przez 25 lat w Krynicy. We Lwowie prowadził prywatny gabinet dermatologiczny i hydroterapeutyczny. Był członkiem licznych organizacji lekarskich i od 1891 roku bibliotekarzem Towarzystwa Lekarskiego Lwowskiego (uporządkował księgozbiór i wydał Spis dzieł lekarskich będących własnością Towarzystwa Lekarzy Galicyjskich obejmujący ponad 4 tys. dzieł ${ }^{68}$. Lekarzem zdrojowym był także Józef Dukiet (1847-1921), związany zwłaszcza z Rymanowem, do którego popularyzacji bardzo się przyczynił. Był autorem pierwszych publikacji o tym uzdrowisku (m.in. Rymanów, zakład zdrojowo-kapielowy, 1882), doprowadził do jego rozbudowy i wprowadzał nowe metody leczenia (np. gimnastykę i masaże ${ }^{69}$.

Do szanowanych i zasłużonych obywateli Krakowa należał Jan Buszek (1845-1901), który w latach 1870-1874 uzyskał stopień doktora medycyny, chirurgii i tytuł magistra położnictwa na Uniwersytecie Jagiellońskim. Jeszcze jako student pracował $\mathrm{w}$ charakterze asystenta u prof. Lucjana Rydla, następnie jako lekarz miejski i sądowy. W czasie panującej w Krakowie cholery w 1873 roku z narażeniem życia pomagał chorym w szpitalu cholerycznym, przyczyniając się do opanowania epidemii. Położył duże zasługi dla miasta na polu higieniczno-sanitarnym, w 1880 roku mianowano go lekarzem naczelnym Krakowa. Działalność praktyczną łączył z pracą naukową, dydaktyczną i społeczną (m.in. w Towarzystwie Dobroczynności i Towarzystwie Ratunkowym $)^{70}$.

${ }^{66}$ Rkp. 4498, k. 15; Corpus..., T-Ż, s. 467-468; PSB, t. XIII, s. 332-333; Stownik leka$r z y$, t. 5, s. 218-219.

${ }^{67}$ Rkp. 4498, k. 6; Corpus..., A-D, s. 754; Słownik lekarzy, t. 3, s. 122.

${ }^{68}$ Rkp. 4498, k. 24; Corpus..., A-D, s. 767; PSB, t. V, s. 137-138; Słownik lekarzy, t. 3, s. $122-123$.

${ }^{69}$ Rkp. 4498, k. 43; Corpus..., A-D, s. 872; Słownik lekarzy, t. 4, s. 111.

${ }^{70}$ Rkp. 4498, k. 56; Corpus..., A-D, s. 497; PSB, t. III, s. 149; Słownik lekarzy, t. 3, s. 64-65; M. Nowakowska-Zamachowska, Towarzystwo Lekarskie Krakowskie 1866-1914. Komisja Balneologiczna, Kraków 2008, s. 37 [praca doktorska], http://dl.cm-uj.krakow. pl:8080/Content/1034/Doktorat_monika-080212ok.pdf [dostęp: 7.07.2017]. 
Lekarzem z zawodu, a botanikiem z zamiłowania był Kazimierz Filipowicz (1845-1891), który rozpoczęte na Uniwersytecie Jagiellońskim studia ukończył w Würzburgu w 1870 roku uzyskaniem dyplomu doktorskiego. Praktykował m.in. w Warszawie i Brześciu Litewskim. Oprócz medycyny, zachęcony przez swojego wuja Tytusa Chałubińskiego, zajmował się także botanika, zbierał i badał mchy i porosty. Wynikiem tych zainteresowań były liczne prace przyrodnicze, m.in. Spis mchów, wątrobowców i porostów z niektórych stanowisk Królestwa Polskiego (1881), Rośliny skrytokwiatowe (1884) czy przeróbka francuskiego podręcznika Emmanuela Le Maouta Wiadomości początkowe z botaniki $(1884)^{71}$.

Większość studentów Wydziału Lekarskiego, którzy wpisali się do albumu dla Libelta, po ukończeniu nauki czekała zwykła praca w zawodzie. Tak np. Karol Dworzański (1842-1930) w 1877 roku, w dwa lata po uzyskaniu tytułu doktora, zamieszkał w Kętach, z którymi związał się już do końca życia. Był lekarzem miejskim i burmistrzem tego miasta $^{72}$. Władysław Czyżewicz (1850-1918) praktykował jako lekarz powiatowy w Wadowicach, Myślenicach, Dąbrowie i Sanoku. Działał w Towarzystwie Lekarzy Galicyjskich, a w 1907 roku założył „Związek lekarzy urzędowych w Galicji", którego został pierwszym prezesem ${ }^{73}$. Stefan Dobrzański (1849-1915) w latach 1893-1911 był lekarzem więziennym w Kielcach, w okresach letnich praktykował jako lekarz zdrojowy w Busku ${ }^{74}$. Maurycy Drewiński (1845-1916) związał swoje życie zawodowe $\mathrm{z}$ rodzinnym Sanokiem, kierował tamtejszym szpitalem, pracował jako lekarz w Sanockiej Fabryce Wagonów, wreszcie udzielał się aktywnie w różnych miejscowych organizacjach, jak np. Towarzystwo Gimnastyczne "Sokół"75. Józef Danek (ur. 1845) pracował m.in. jako lekarz Zarządu Salinarnego (kopalni soli) w Drohobyczu, Stebniku i Dolinie, gdzie ponadto był lekarzem miejskim ${ }^{76}$. Jan Bobek (ur. 1846) uzyskał dyplom „doktora wszech nauk lekarskich" w 1874 roku i jako medyk pracował w Potoku Złotym w galicyjskim powiecie buczackim w latach 1875-1914. Dużo wcześniej, będąc uczniem III klasy gimnazjum w Tarnowie, brał udział w powstaniu styczniowym w oddziale Edwarda Dunajewskiego, za co odbył karę więzienia. W książce pamiątkowej $W$ czterdziesta rocz-

${ }^{71}$ Rkp. 4498, k. 29; Corpus..., E-J, s. 116-117; PSB, t. VI, s. 456; Stownik lekarzy, t. 1, s. $177-178$.

${ }^{72}$ Rkp. 4498, k. 29; Corpus..., A-D, s. 894; Słownik lekarzy, t. 5, s. 123.

${ }^{73}$ Rkp. 4498, k. 4; Corpus..., A-D, s. 700; Stownik lekarzy, t. 3, s. 111.

${ }^{74}$ Rkp. 4498, k. 39; Corpus..., A-D, s. 806; Stownik lekarzy, t. 3, s. 135.

75 Rkp. 4498, k. 4; Corpus..., A-D, s. 836; Stownik lekarzy, t. 4, s. 102.

${ }^{76}$ Rkp. 4498, k. 25; Corpus..., A-D, s. 713; Stownik lekarzy, t. 4, s. 65. 
nice powstania styczniowego (Lwów 1903) ukazały się jego wspomnienia $\mathrm{z}$ tego czasu $^{77}$. Karol Muszkiet (ur. 1846), chirurg i okulista, był lekarzem miejskim w Żółkwi i przez ponad 35 lat kierował tamtejszym szpitalem ${ }^{78}$. Wilhelm Beym (ur. 1847) rozpoczął studia lekarskie na Uniwersytecie Jagiellońskim w 1867 roku, a zakończył dopiero w 1882 roku uzyskaniem dyplomu na Uniwersytecie w Dorpacie. Był tam członkiem studenckiego Konwentu „Polonia”. Praktykował w Krakowskiem ${ }^{79}$.

Wśród adeptów medycyny wpisanych do albumu byli i tacy, których można nazwać "ofiarami zawodu”. Tak np. Franciszek Kostecki (1848-1875) w niespełna rok po uzyskaniu dyplomu lekarskiego (30 maja 1874) podczas pracy w szpitalu św. Łazarza w Krakowie zakaził się tyfusem plamistym i zmarł, mając zaledwie 25 lat (23 marca 1875) $)^{80}$. W wieku 33 lat, podczas epidemii tyfusu w Łańcucie, zmarł znakomicie się zapowiadający chirurg Marian Krzykowski (1846-1879). Wcześniej pracował w szpitalu w Sanoku, gdzie m.in. w 1875 roku wykonał drugą w Polsce udokumentowaną i udaną transfuzję krwi u chorej wykrwawionej po porodzie. Uznaje się go za pioniera polskiej transfuzjologii ${ }^{81}$. Tyfus plamisty przerwał także karierę naukową Juliusza Zawilskiego (1847-1877), który jeszcze w trakcie studiów został asystentem w Zakładzie Fizjologii Uniwersytetu Jagiellońskiego, a już jego pierwsze prace na temat przemiany materii człowieka były uznawane za wysoce cenne ${ }^{82}$. Ofiarą tyfusu był również Maurycy Schlank (1845-1916), długoletni lekarz miejski w Oświęcimiu i w latach 1876-1878 zastępca burmistrza tego miasta ${ }^{83}$.

Wydział Filozoficzny Uniwersytetu Jagiellońskiego w 1869 roku dzielił się na dwa oddziały: filozoficzno-historyczno-filologiczny i matematyczno-przyrodniczy ${ }^{84}$. Jego słuchacze, którzy w liczbie 55 wpisali się do albumu dla Libelta, mieli w przyszłości zostać m.in. nauczycielami różnych przedmiotów, filologami, bibliotekarzami, chemikami, historykami, geografami czy farmaceutami.

77 Rkp. 4498, k. 15; Corpus..., A-D, s. 317; Stownik lekarzy, t. 5, s. 45.

${ }^{78}$ Rkp. 4498, k. 56; Corpus..., M-N, s. 585; Stownik lekarzy, t. 2, s. 200.

${ }^{79}$ Rkp. 4498, k. 27; Corpus..., A-D, s. 216; Stownik lekarzy, t. 5, s. 32.

${ }^{80}$ Rkp. 4498, k. 34; Corpus..., K-E, s. 453; Stownik lekarzy, t. 4, s. 219.

${ }^{81}$ Rkp. 4498, k. 2; Corpus..., K-E, s. 668; Stownik lekarzy, t. 2, s. 150-151; R. Paliga, Krwiolecznictwo i krwiodawstwo w medycynie polskiej XIX i XX wieku (1830-1951): od powstania listopadowego do utworzenia Instytutu Hematologii, Poznań 2012 [praca doktorska], http://www.wbc.poznan.pl/publication/301302 [dostęp: 9.07.2017].

${ }^{82}$ Rkp. 4498, k. 40; Corpus..., T-Ż, s. 826; Słownik lekarzy, t. 1, s. 609-610.

${ }^{83}$ Rkp. 4498, k. 9; Corpus..., S-Ś, s. 100; Stownik lekarzy, t. 4, s. 341.

${ }^{84}$ Kronika Uniwersytetu Jagiellońskiego..., s. 75. 


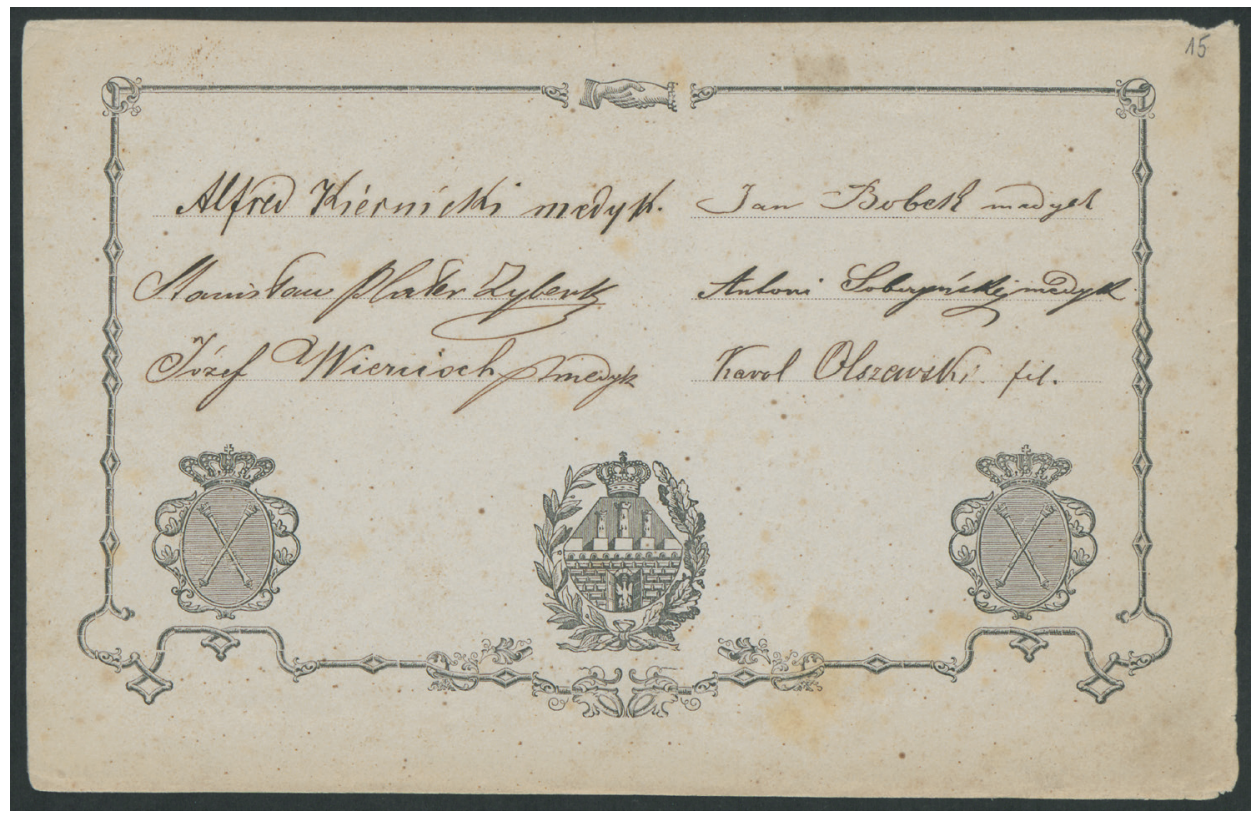

Il. 7. Karta z podpisem Karola Stanisława Olszewskiego (1846-1915)

Z określeniem przy nazwisku „filozof" lub „sł[uchacz] filozofii” wpisało się 37 osób. Wśród nich znalazł się Karol Stanisław Olszewski (1846-1915, il. 7), wybitny chemik i kriogenik, cieszący się bardzo dużym uznaniem $\mathrm{w}$ międzynarodowym środowisku naukowym. Studiował w Krakowie (w 1873 roku został docentem chemii) i Heidelbergu (w 1872 roku otrzymał dyplom doktora filozofii). Związał się z Uniwersytetem Jagiellońskim, gdzie od 1891 roku był profesorem zwyczajnym i kierownikiem Zakładu Chemii Nieorganicznej. W 1883 roku przystąpił do swych przełomowych badań nad skraplaniem gazów (prowadził je najpierw wspólnie z Zygmuntem Wróblewskim, a później sam). Jako pierwszy na świecie przeprowadził skroplenie w stanie statycznym tlenu, azotu i tlenku węgla. Badania w dziedzinie kriogeniki, które kontynuował aż do śmierci, przyniosły mu sławę wybitnego uczonego. Zajmował się ponadto analizą chemiczną i elektrochemią, działalnością dydaktyczną na uniwersytecie, był też członkiem towarzystw naukowych (m.in. krakowskiej i praskiej Akademii Umiejętności). Opublikował ponad 110 prac z kriogeniki i ponad $20 \mathrm{z}$ innych dziedzin, $\mathrm{w}$ tym ogrodnictwa, któremu poświęcał się w wolnych chwilach (napisał m.in. książkę Hodowla chryzantem). Cały swój majątek przeznaczył anonimowo na fundusz badań z zakresu chemii, a pozostawione przez 


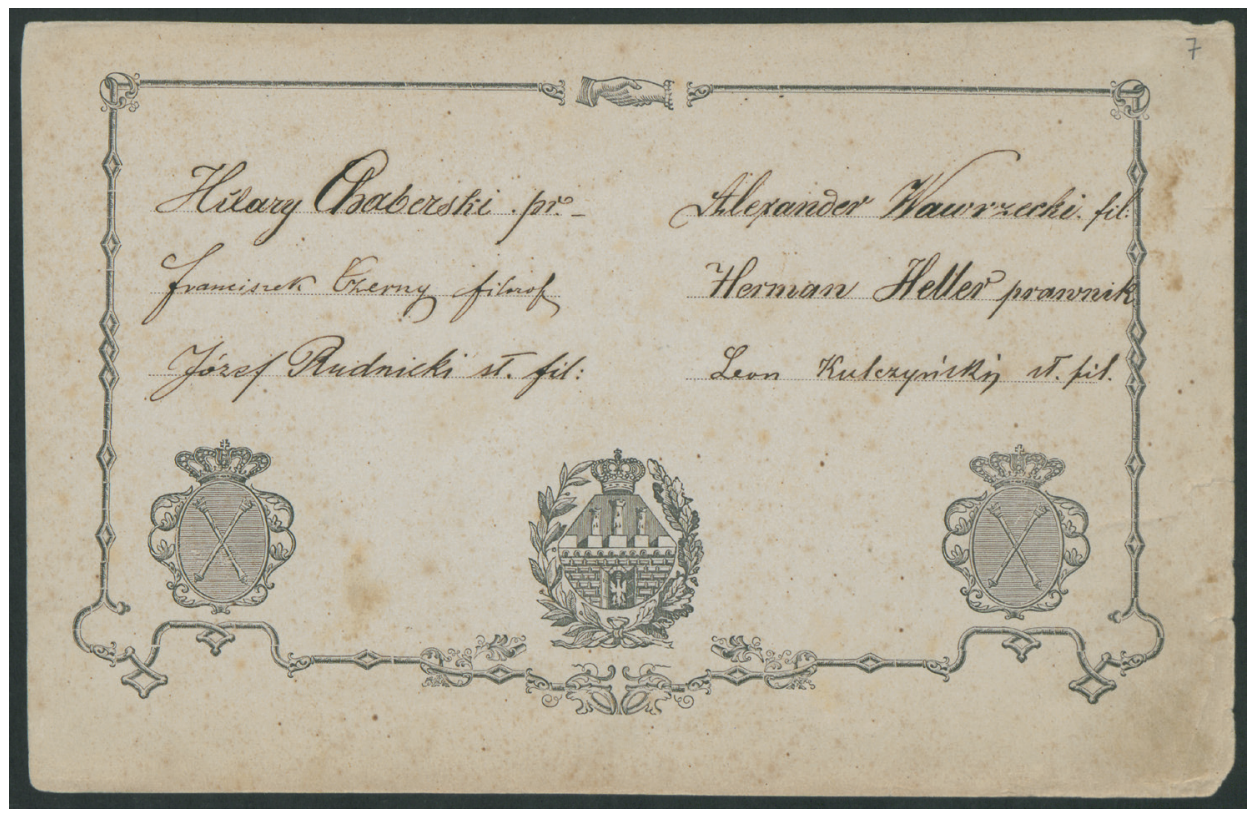

Il. 8. Karta z podpisami Franciszka Czernego-Schwarzenberga (1847-1917) i Leona Kulczyńskiego (1847-1932)

niego w spadku wyposażenie jego pracowni dało początek Muzeum Uniwersytetu Jagiellońskiego ${ }^{85}$.

Zasługi dla swojej macierzystej uczelni położył też Franciszek Czerny-Schwarzenberg (1847-1917, il. 8), choć nie w dziedzinie, w której się tam doktoryzował. W 1871 roku został doktorem filozofii $\mathrm{w}$ zakresie nauk historycznych, zdobył uprawnienia nauczycielskie i przez rok pracował m.in. w krakowskim Gimnazjum św. Anny. Przełomem dla niego okazał się wyjazd na stypendium do Wiednia i Lipska, gdzie udał się celem pogłębienia swych studiów geograficznych. Po powrocie w 1876 roku objął reaktywowaną na Uniwersytecie Jagiellońskim Katedrę Geografii, stając się w ten sposób następcą Wincentego Pola, a rok później został profesorem nadzwyczajnym UJ (zwyczajnym w 1887 roku). Przez blisko 40 lat kierowania katedrą zajmował się pracami naukowymi (opublikował m.in. Zmienność klimatu i jej przyczyny, 1877; Zarys rozwoju wiedzy o ziemi na tle odkryć geograficznych, 1880; Dzisiejszy stan geografii, jej badań i wiadomości, 1882 i Ogólna geografia handlowa, 1889), dydaktyką (prowadził wykłady, wspierał działalność studenckiego Koła Geografów) i pedagogiką

${ }^{85}$ Rkp. 4498, k. 15; Corpus..., O-Q, s. 67; PSB, t. XXIV, s. 27-30; Biogramy uczonych polskich, cz. 3: Nauki ścisłe, Wrocław 1986, s. 281-286; U. Perkowska, Corpus Academicorum Facultatis Philosphiae Universitatis Iagellonicae 1850-1945, Kraków 2007, s. 272. 
(był od 1891 roku kierownikiem komisji egzaminacyjnej dla kandydatów na nauczycieli szkół średnich). Prace Czernego przygotowały grunt pod nowoczesną geografię polska, ale on sam jako naukowiec został zapomniany. W życiu prywatnym, o czym warto wspomnieć, jego szwagrem był Michał Bobrzyński, polityk i profesor UJ, którego wpis także znajduje się $\mathrm{w}$ albumie dla Karola Libelta ${ }^{86}$. Z kolei przyjacielem i bliskim współpracownikiem Bobrzyńskiego był Leon Kulczyński (1847-1932, il. 8), studiujący na Wydziale Filozoficznym Uniwersytetu Jagiellońskiego języki klasyczne i jednocześnie uczęszczający na wykłady m.in. filozofii oraz literatury niemieckiej i polskiej. Po uzyskaniu stopnia doktora filozofii w 1872 roku rozpoczął studia z zakresu pedagogiki i w 1880 roku po habilitacji jako pierwszy $\mathrm{w}$ historii uniwersytetu krakowskiego został docentem prywatnym prowadzącym wykłady z pedagogiki. Teorię łączył z praktyka, pracując najpierw jako nauczyciel III Gimnazjum im. Jana III Sobieskiego, a później (w latach 1887-1922) dyrektor Gimnazjum św. Anny w Krakowie (którego zresztą był absolwentem). Był też członkiem komisji egzaminacyjnych, przygotowywał do zawodu kandydatów na nauczycieli, uczestniczył w zagranicznych zjazdach filologów i pedagogów, był wreszcie autorem licznych publikacji pedagogicznych (jego Ogólne zasady pedagogiki miały kilka wydań) ${ }^{87}$.

W zawodzie nauczyciela realizował się także Henryk Stroka (1839-1896), uczestnik powstania styczniowego. Po ukończeniu studiów w 1870 roku podjął pracę w Gimnazjum św. Jacka w Krakowie, a w latach 1872-1879 był starszym nauczycielem języka polskiego, historii i geografii w Państwowym Seminarium Nauczycielskim Męskim. Przeniesiono go stamtąd do seminarium nauczycielskiego w Rzeszowie. Tam zaczął publikować opracowania poświęcone metodyce nauczania języka polskiego w szkole ludowej, pisał dramaty, nowele i poezje, wygłaszał odczyty. Aktywnie uczestniczył w działalności organizacji oświatowych (m.in. Towarzystwa Nauczycieli Szkół Wyższych, Towarzystwa Szkoły Ludowej) i był animatorem życia kulturalnego w Rzeszowie ${ }^{88}$. Tamtejsze gimnazjum ukończył Ignacy Przybyłkiewicz (1846-1898), po studiach związany przede wszystkim jako nauczyciel matematyki i fizyki z gimnazjum w Tarnowie. W związku z powierzeniem mu w 1883 roku prowadzenia zajęć

${ }^{86}$ Rkp. 4498, k. 7; Corpus..., A-D, s. 682; PSB, t. IV, s. 344-345; U. Perkowska, op.cit., s. 53-54; A. Krawczyk, Franciszek Czerny-Schwarzenberg 1847-1917, w: Wybitni geografowie Uniwersytetu Jagiellońskiego, Kraków 1999, s. 21-35.

${ }^{87}$ Rkp. 4498, k. 7, 20; Corpus..., K-E, s. 733; PSB, t. XVI, s. 140-141; U. Perkowska, op.cit., s. 197.

${ }^{88}$ Rkp. 4498, k. 11; Corpus..., S-Ś, s. 651; PSB, t. XLIV, s. 354-356. 
z gimnastyki zainteresował się problematyką wychowania fizycznego, której z czasem stał się gorącym propagatorem. Założył w Tarnowie Towarzystwo Gimnastyczne "Sokół”, wygłaszał odczyty o kulturze fizycznej, publikował artykuły na ten temat $\mathrm{w}$ miejscowej prasie, był też organizatorem kolonii letnich dla młodzieży i założycielem klubu cyklistów $^{89}$. Absolwentem Wydziału Filozoficznego i asystentem Zakładu Fizyki Uniwersytetu Jagiellońskiego w latach 1873-1876 był Stanisław Jaworski (1850-1916). Później pracował jako nauczyciel matematyki i fizyki w gimnazjach w Jaśle, Rzeszowie i Krakowie, aż w końcu został dyrektorem własnego prywatnego gimnazjum realnego w Krakowie ${ }^{90}$. Józef Bitner (1842-1898) uczył matematyki w szkole rolniczej w Czernichowie i szkole realnej w Stanisławowie ${ }^{91}$.

Jako słuchacz Wydziału Filozoficznego w albumie dla Karola Libelta wpisał się Stanisław Domański (1844-1916, il. 9). Był nim rzeczywiście w roku akademickim 1868/69, ale wcześniej, w 1868 roku uzyskał stopień doktora nauk medycznych jako student Wydziału Lekarskiego i właśnie z medycyną związał swoje życie zawodowe. Był profesorem neurologii Uniwersytetu Jagiellońskiego, znanym w środowisku lekarskim jako członek Towarzystwa Lekarskiego Krakowskiego, redaktor naczelny „Przeglądu Lekarskiego" i jeden z głównych autorów Słownika polskiej terminologii lekarskiej. Przez ponad 30 lat był członkiem Rady Miejskiej Krakowa i autorem licznych rozpraw i artykułów z zakresu neurologii i higieny publicznej ${ }^{92}$.

W pamiątce podarowanej Libeltowi 18 osób podpisało się z określeniem "farmaceuta". Trudno jest odtworzyć ich życiorysy, w źródłach przeważnie pojawiają się szczątkowe informacje dotyczące ich pracy w rozproszonych głównie po całej Galicji aptekach. Tak np. Czesław Chorubski według danych z jego ankiety wpisowej urodził się w 1847 roku w Krzeszowicach, a jego opiekunem był Fortunat Gralewski, aptekarz zamieszkały w Krakowskiem. Chorubski studiował na Wydziale Filozoficznym w latach 1868-1872, naukę ukończył 17 grudnia 1872 roku, uzyskując tytuł magistra farmacji. O jego pracy zawodowej wiadomo tyle, że przez

${ }^{89}$ Rkp. 4498, k. 12; Corpus..., O-Q, s. 638-639; E. Stańczyk, Ignacy Przybyłkiewicz 1846-1898, w: B. Sawczyk, M. Sąsiadowicz, E. Stańczyk, Ocalić od zapomnienia... Patroni tarnowskich ulic, t. 2: O-Ż, Tarnów 2004, s. [34-36].

${ }^{90}$ Rkp. 4498, k. 12; Corpus..., E-J, s. 1023; U. Perkowska, op.cit., s. 140-141; Kronika Uniwersytetu Jagiellońskiego..., s. 81.

91 Rkp. 4498, k. 51; Corpus..., A-D, s. 288; J. Latosiński, Monografia Miasteczka Wilamowic, Kraków 1909, s. 351.

${ }^{92}$ Rkp. 4498, k. 24; Corpus..., A-D, s. 819-820; PSB, t. V, s. 302. 


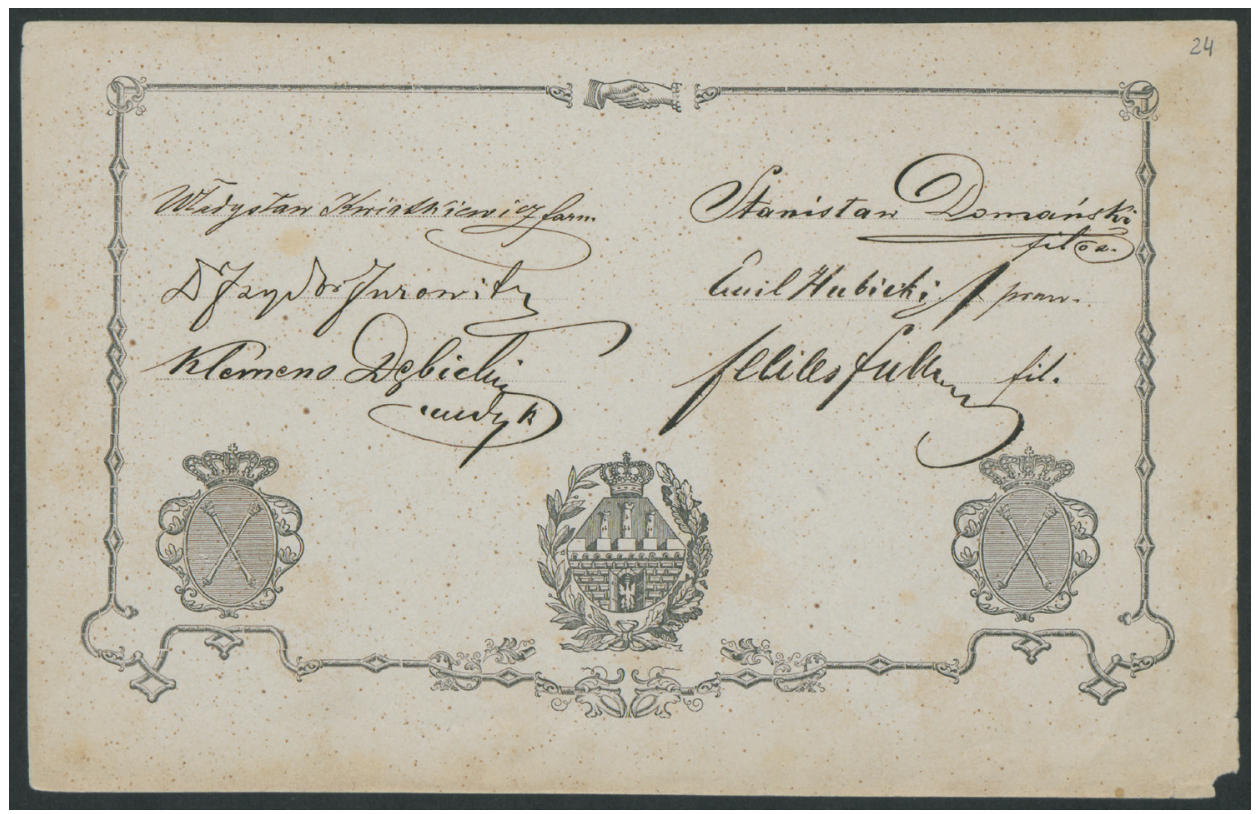

Il. 9. Karta z podpisem Stanisława Domańskiego (1844-1916)

pewien czas był kierownikiem apteki w Dynowie ${ }^{93}$. Z kolei nazwisko Kazimierza Kamienobrodzkiego (ur. 1846), magistra farmacji z 1871 roku, zamieszkałego prawdopodobnie we Lwowie, pojawia się $\mathrm{w}$ spisie kandydatów ubiegających się o koncesję na aptekę w Bochni w 1899 roku $^{94}$. Nieco więcej wiadomo o Manswecie Kaczyńskim (1851-1895), który do albumu dla Libelta wpisał się z określeniem „fil.", jako że studiował na Wydziale Filozoficznym. Ukończył go z tytułem magistra farmacji w 1875 roku. Był pierwszym właścicielem apteki w Krościenku nad Dunajcem, do której założenia doprowadził tamtejszy lekarz Franciszek Gumowski w 1883 roku. Kaczyński był też działaczem społecznym, naczelnikiem Towarzystwa Straży Ogniowej oraz członkiem Towarzystwa Aptekarskiego i Towarzystwa Tatrzańskiego ${ }^{95}$.

${ }^{93}$ Rkp. 4498, k. 51; Corpus..., A-D, s. 571; L. Czyż, Przyczynek do dziejów apteki $w$ Dynowie, https://marychna.witkowscy.net/index.php?option=com_content\&view=article\&id=97:przyczynek-do-dziejow-apteki-w-dynowie\&catid=91\&Itemid=505 [dostęp: 10.07.2017].

${ }^{94}$ Rkp. 4498, k. 22; Corpus..., K-Ł, s. 55; „Kronika Farmaceutyczna” 1899, nr 1, s. 10. Bardziej znany od Kazimierza Kamienobrodzkiego był jego starszy brat - Alfred (1844-1922), architekt i malarz akwarelista (zob. PSB, t. XI , s. 522-523).

${ }^{95}$ Rkp. 4498, k. 50; Corpus..., K-七, s. 24-25; M. Bilek, Historia apteki w Krościenku nad Dunajcem, „Farmacja Krakowska”, R. IX, 2006, nr 3, s. 22-23. 
Słuchaczami Wydziału Teologicznego Uniwersytetu Jagiellońskiego byli głównie alumni seminariów duchownych, którzy przygotowywali się do pracy duszpasterskiej ${ }^{96}$. Do albumu dla Karola Libelta, najczęściej z określeniem „słuchacz teol[ogii]" lub po prostu "teolog", wpisało się ich 36. Większość z nich, o ile ukończyło obrany kierunek ${ }^{97}$, zostało księżmi w małych parafiach, trudno wśród nich znaleźć znaczące nazwisko, co może mieć także związek z kryzysem, który Wydział Teologiczny wówczas przechodził ${ }^{98}$. Ze słuchaczy teologii widniejących na kartach albumu karierę $\mathrm{w}$ sferach kościelnych zrobił ks. Władysław Józefczyk (1848-1893), student Uniwersytetu Jagiellońskiego i alumn seminarium stradomskiego, późniejszy kanonik katedralny krakowski i kanclerz konsystorza biskupiego krakowskiego ${ }^{99}$. W słownikach biograficznych pojawia się postać ks. Jakuba Zycha (1842-1917), wieloletniego proboszcza w Rabce i budowniczego nowego kościoła pw. św. Marii Magdaleny ${ }^{100}$. Ks. Michał Sopata (1843-1884), wikariusz w parafii Wierzchosławice i proboszcz parafii Biegonice, który chrzcił w 1874 roku Wincentego Witosa, wiódł „żywot cichy a pełen cnót i uczynków”101. Ks. Feliks Gątkiewicz (1847-1905) był proboszczem w Olejowie i Sokalu ${ }^{102}$, a ks. Jan Kolstrąg (1844-1899) w Czulicach ${ }^{103}$. Działalnością naukową zajmował się

96 A.K. Banach, op.cit., s. 120.

${ }_{97}$ Np. Jan Stramski (Rkp. 4498, k. 6) w roku akademickim 1868/69 był słuchaczem Wydziału Teologicznego, a później przeniósł się na Wydział Filozoficzny. Zob. Corpus..., S-Ś, s. 635.

98 Począwszy od końca lat 40. XIX wieku, „,całe następne 30-lecie to okres głębokiego upadku Wydziału, który wtedy zaledwie wegetował. Na ten smutny stan złożyły się przede wszystkim takie czynniki, jak zbyt mała liczba katedr (było ich 4), nadto często latami nieobsadzanych, zupełnie nikła ilość studentów, brak sił profesorskich na poziomie prawdziwie akademickim, niski poziom wykładów, wreszcie [...] zawieszenie prawa promowania doktorów". S. Dobrzanowski, Wydział Teologiczny Uniwersytetu Jagiellońskiego w latach 1849-1890, "Studia Theologica Varsaviensia” 10, 1972, nr 2, s. 68.

99 Rkp. 4498, k. 13; Corpus..., E-J, s. 1073-1074; M. Hałaburda, J. Szczepaniak, Katalog alumnów Seminarium na Stradomiu (1801-1900), Kraków 2006, s. 98; Józefa Czecha kalendarz krakowski na rok 1893, Kraków 1893, s. 98.

100 Rkp. 4498, k. 33; Corpus..., T-Ż, s. 920-921; M. Olszowska, E. Trybowska, Słownik biograficzny Rabki, wyd. 2, Kraków-Rabka-Zdrój 2012, s. 342.

101 Rkp. 4498, k. 14; Corpus..., S-Ś, s. 435; R. Kucharski, Wierzchosławice w hołdzie śp. ks. Michałowi Sopacie, w 125 rocznice Jego śmierci, "Ziemia Wierzchosławicka" 2009, nr 1 (68), s. 13-14.

102 Rkp. 4498, k. 50; Corpus..., E-J, s. 304; Historia Zgromadzenia SS. Felicjanek. Na podstawie rękopisów, cz. 2, Kraków 1929, s. 109, 111, 112, 117, 119, 120.

103 Rkp. 4498, k. 14; Corpus..., K-乇, s. 334; Kronika. Wiadomości kościelne, „Gazeta Lwowska" 1899, nr 166. 
ks. Franciszek Namysłowski (ur. 1847), autor rękopiśmiennego Katalogu biblioteki księży Misjonarzy w Krakowie na Stradomiu z 1889 roku ${ }^{104}$.

Poza studentami Uniwersytetu Jagiellońskiego do albumu dla Karola Libelta wpisali się uczniowie krakowskiego Instytutu Technicznego. Ta powstała w 1834 roku szkoła, od 1854 roku mająca status akademii technicznej, prowadziła kształcenie ogólne i zawodowe na zróżnicowanych kierunkach (inżynieryjnym, poligraficznym czy artystycznym) i wykształciła kilka pokoleń techników o dobrym przygotowaniu zawodowym. Wpisów słuchaczy tego instytutu jest zaledwie kilkadziesiąt - określenie "technik" pojawia się przy 53 odczytanych nazwiskach. Najbardziej znaczący wśród nich zdaje się wpis Wincentego Wdowiszewskiego (1850-1906), który studia zawodowe w Instytucie Technicznym ukończył w 1870 roku, a później wsławił się m.in. jako inżynier i inspektor budownictwa miejskiego w Krakowie, historyk sztuki i pisarz ${ }^{105}$. Z określeniem "technik" wpisał się również Tadeusz Barącz (1849-1905), studiujący w latach 1868-1869 w Szkole Sztuk Pięknych w Krakowie rzeźbiarz i medalier, twórca licznych rzeźb portretowych i pomników ${ }^{106}$. Jeden z wpisów należy do Stanisława Arndta (1851-1888), inżyniera, budowniczego Kolei Nadwiślańskiej i wodociągów warszawskich ${ }^{107}$, a inny do Tomasza Wilhelma Dangela (1851-1926) ${ }^{108}$, inżyniera, ojca Józefa (1883-1952), znanego hutnika i działacza społecznego.

Z hasłem "uczeń/szkoła sztuk pięknych" wpisała się tylko jedna osoba, ale za to dwukrotnie - był to Tomasz Łosik (1848-1896), malarz, grafik i rzeźbiarz, działający w Paryżu i rodzinnej Bochni, który w latach 1865-1872 studiował w krakowskiej Szkole Sztuk Pięknych u Władysława Łuszczkiewicza, a następnie w akademii monachijskiej ${ }^{109}$.

${ }^{104}$ Rkp. 4498, k. 31; Corpus..., M-N, s. 640; W. Umiński, Biblioteka Zgromadzenia Księży Misjonarzy w Krakowie na Stradomiu - przeszłość i teraźniejszość, „Bibliotheca Nostra" 2009, nr 2 (18), s. 39, 43.

105 Rkp. 4498, k. 17. We wspomnieniu pośmiertnym Wincentego Wdowiszewskiego znalazł się celny opis Instytutu Technicznego w Krakowie: „chociaż prowadzony tanio i niezaopatrzony w obfite środki naukowe, dzięki poświęceniu swego grona profesorskiego i duchowi obywatelskiemu, jaki zacne to grono ożywiał, wychował liczny zastęp dzielnych sił technicznych na pożytek polskiego społeczeństwa". E. Śmiałowski, Wspomnienie pośmiertne. Wincenty Julian Wdowiszewski, "Architekt” 1906, z. 3, s. 70.

106 Rkp. 4498, k. 21; PSB, t. I, s. 292-293; Słownik artystów polskich i obcych w Polsce działajacych. Malarze, rzeźbiarze, graficy, t. 1: A-C, Wrocław 1971, s. 86-88.

107 Rkp. 4498, k. 18; Słownik biograficzny techników polskich, z. 3, Warszawa 1993, s. 14.

108 Rkp. 4498, k. 18.

109 Rkp. 4498, k. 25, 37; Słownik artystów polskich i obcych w Polsce działajacych (zmartych przed 1966 r.). Malarze, rzeźbiarze, graficy, t. 5: Le-M, Wrocław 1993, s. 181-182. 
Zawierający 348 podpisów album jest przede wszystkim pamiątką z podróży naukowej Karola Libelta do Galicji. Jest też wyrazem uznania, swoistego hołdu złożonego mu przez studentów krakowskich uczelni. Pozostaje wreszcie cennym zbiorem autografów osób, które w 1869 roku wpisały się na karty albumu dla wielkiego filozofa, a z których wielu później dzięki swojej działalności zapisało się na stałe na kartach polskiej historii. Warto odnotować choć kilka nazwisk - profesorów Uniwersytetu Jagiellońskiego: Michała Hieronima Bobrzyńskiego, Tadeusza Browicza, Karola Żuławskiego, Karola Stanisława Olszewskiego, Franciszka Czernego-Schwarzenberga czy Stanisława Domańskiego.

$\mathrm{Na}$ koniec warto wspomnieć, iż podarowany Bibliotece Raczyńskich rękopiśmienny album ${ }^{110}$ uzupełnia materiały dotyczące Karola Libelta znajdujące się $\mathrm{w}$ zbiorach specjalnych biblioteki, tj. m.in. napisaną własnoręcznie przez filozofa jego autobiografię w języku niemieckim z 1862 roku (Rkp. 411/8), niedatowane Compendium literatury polskiej z uwagami marginesowymi Libelta (Rkp. 1498) czy jego listy do Augusta Cieszkowskiego (Rkp. 1654, 2209), Juliana Ochorowicza (Rkp. 1419) i Zygmunta Szułdrzyńskiego (Rkp. 2795).

\section{Bibliografia}

Źródła

Józefa Czecha kalendarz krakowski na rok 1893, Kraków 1893.

Korespondencja Karola Libelta z lat 1849-1875, t. I, Biblioteka Jagiellońska w Krakowie, sygn. Rkp. 6004 III, t. I - Jagiellońska Biblioteka Cyfrowa, http://jbc.bj.uj. edu.pl/publication/396392 [dostęp: 2.07.2017].

Korespondencja Karola Libelta z lat 1849-1875, t. II, Biblioteka Jagiellońska w Krakowie, sygn. Rkp. 6004 III, t. II - Jagiellońska Biblioteka Cyfrowa, http://jbc. bj.uj.edu.pl/publication/396391 [dostęp: 2.07.2017].

Libelt K., Listy, zebrał, oprac. i wstępem poprzedził Z. Grot, Warszawa 1978.

Pamiątka dla Karola Libelta od Krakowskich Akademików, Biblioteka Raczyńskich w Poznaniu, sygn. Rkp. 4498.

Prasa

"Architekt" 1906, z. 3.

"Czas" 1869, nr 82, 84, 87-89; 1900, nr 305; 1920, nr 103; 1924, nr 103.

„Dziennik Literacki” 1869, nr 15.

„Dziennik Poznański” 1869, nr 86, 89-93.

${ }^{110}$ Jako ciekawostkę należy odnotować, że do albumu dołączone były, niewątpliwie później dodane, ozdobny klucz i kartka z informacją: „Klucz od trumny ś.p. teścia mego Karola Libelta. Spoczywa pod Kościołem w Czeszewie p. Gołańczą”. 
„Gazeta Lwowska” 1899, nr 166; 1917, nr 50.

„Gazeta Narodowa” 1869, nr 83, 90.

„Głos Rzeszowski” 1914, nr 7.

"Ilustrowany Kuryer Codzienny” 1938, nr 323.

„Kronika Farmaceutyczna” 1899, nr 1.

„Kurier kolejowy i asekuracyjny” 1911, nr 11.

„Lwowski Tygodnik Lekarski” 1908, nr 12.

„Nowa Reforma” 1911, nr 130.

\section{Literatura}

12 VI 1890: Kamienica Jana i Karoliny Turnau'ów w Krakowie, http://kalendariumdawnejprasy.blogspot.com/2014/06/12-vi-1890-kamienica-jana-i-karoliny. html [dostęp: 7.07.2017].

Banach A.K., Czasy zaborów. Uniwersytet Jagielloński w latach 1795-1918, w: K. Stopka, A.K. Banach, J. Dybiec, Dzieje Uniwersytetu Jagiellońskiego, Kraków 2000, s. 85-162.

Bilek M., Historia apteki w Krościenku nad Dunajcem, „Farmacja Krakowska”, R. IX, 2006, nr 3, s. 22-28.

Biogramy uczonych polskich, cz. 1: Nauki społeczne, z. 1: A-J, Wrocław 1983.

Biogramy uczonych polskich, cz. 3: Nauki ścisłe, Wrocław 1986.

Ciszyńska M., Tadeusz Browicz (1847-1928), „Medyk Białostocki” 2010, nr 84, s. 17-18.

Corpus studiosorum Universitatis Iagellonicae 1850/51-1917/18, A-D, red. J. Michalewicz, Kraków 1999; E-J, red. K. Stopka, Kraków 2006; K-E, red. K. Stopka, Kraków 2009; M-N, red. K. Stopka, Kraków 2011; O-Q, red. K. Stopka, Kraków 2011; R, red. K. Stopka, Kraków 2013; S-Ś, red. K. Stopka, Kraków 2014; T-Ż, red. K. Stopka, Kraków 2015 [Z prac Archiwum Uniwersytetu Jagiellońskiego, seria C: Corpus studiosorum Universitatis Iagellonicae in saeculis XVIII-XX, tomus III].

Czyż L., Przyczynek do dziejów apteki w Dynowie, https://marychna.witkowscy.net/ index.php?option=com_content\&view=article\&id=97:przyczynek-do-dziejow -apteki-w-dynowie\&catid=91\&Itemid=505 [dostęp: 10.07.2017].

Dobrzanowski S., Wydziat Teologiczny Uniwersytetu Jagiellońskiego w latach 1849-1890, „Studia Theologica Varsaviensia” 10, 1972, nr 2, s. 67-103.

Grot Z., Życie i działalność Karola Libelta (1807-1878), Warszawa-Poznań 1977.

Hahn W., Karol Libelt we Lwowie w roku 1869. Wspomnienie w setna rocznice urodzin, Lwów 1907.

Hałaburda M., Szczepaniak J., Katalog alumnów Seminarium na Stradomiu (1801-1900), Kraków 2006.

Herczyńska G., Karol Szeliga Żuławski 1845-1914, „Postępy Psychiatrii i Neurologii" 2001, z. 4 (na okładce).

Historia Zgromadzenia SS. Felicjanek. Na podstawie rękopisów, cz. 2, Kraków 1929. Janicka D., O pionierach nauk kryminologicznych w Polsce, "Czasopismo Prawno-Historyczne" 2016, t. 58, s. 1, s. 29-50.

Karol Libelt 1807-1875, Warszawa-Poznań 1976.

Kosmowska I., Karol Libelt jako działacz polityczny i społeczny, Poznań 1918. 
Kotliński T.J., Poczet sędziów krakowskich, cz. XXXIII, „Krakowskie Zeszyty Sądowe", R. XXVI, 2016, nr 1 (301), s. 49-60.

Kotliński T.J., Sąd Obwodowy w Wadowicach. Jego prezydenci i radcy (1882-1899), „Wadoviana. Przegląd historyczno-kulturalny" 2015, nr 18, s. 26-41.

Kowalska M., Właściciele dworu w Mordarce, „Almanach Sądecki”, R. VII, 1998, nr 3 (24), s. 14-23.

Krawczyk A., Franciszek Czerny-Schwarzenberg 1847-1917, w: Wybitni geografowie Uniwersytetu Jagiellońskiego, Kraków 1999, s. 21-35.

Kronika Uniwersytetu Jagiellońskiego od r. 1864 do $r .1887$ i obraz jego stanu dzisiejszego wraz z rzecza o rektorach od czasów najdawniejszych, Kraków 1887.

Kucharski R., Wierzchosławice w hołdzie śp. ks. Michałowi Sopacie, w 125 rocznice Jego śmierci, „Ziemia Wierzchosławicka” 2009, nr 1 (68), s. 13-14.

Latosiński J., Monografia Miasteczka Wilamozwic, Kraków 1909.

Lombarski J., Piotr Hubal Dobrzański, przyjaciel Jacka Malczewskiego, „Gazeta Radomska" 2016, nr 1, s. 12.

Marian Dydyński - dziedzic Raciborska, http://www.kozmice.pl/47.html\#dydynski [dostęp: 6.07.2017].

Niedokończony dramat dziejowy. Odczytał w dniu 24-tym stycznia 1909 na wieczorku urzadzonym ku pamięci styczniowego powstania [broszura] (Cieszyn, s.a.) wraz z biogramem I. Ślebodzińskiego opracowanym przez A.B. Ślebodzińskiego: https://get.google.com/albumarchive/106561962250549489911/album/AF1QipO8xRsjYG_2gtoY7tE-NuSWPeNLrGm2Kpfuwhx9 [dostęp: 7.07.2017].

Nowakowska-Zamachowska M., Towarzystwo Lekarskie Krakowskie 1866-1914. Komisja Balneologiczna, Kraków 2008, s. 37 [praca doktorska], http://dl.cm-uj.krakow.pl:8080/Content/1034/Doktorat_monika-080212ok.pdf [dostęp: 7.07.2017].

Olszowska M., Trybowska E., Stownik biograficzny Rabki, wyd. 2, Kraków-Rabka-Zdrój 2012.

Paliga R., Krwiolecznictwo i krwiodawstwo w medycynie polskiej XIX i XX wieku (1830-1951): od powstania listopadowego do utworzenia Instytutu Hematologii, Poznań 2012 [praca doktorska], http://www.wbc.poznan.pl/publication/301302 [dostęp: 9.07.2017].

Perkowska U., Corpus Academicorum Facultatis Philosphiae Universitatis Iagellonicae 1850-1945, Kraków 2007.

Polski słownik biograficzny, t. 1-51/2, Kraków-Wrocław-Warszawa 1935-2016.

Posiadała Z.K., Sladami Jacka Malczewskiego, Radom 2012.

Puciata-Pawłowska J., Jacek Malczewski, Wrocław 1968.

Pudłocki T., Burmistrz Franciszek Doliński - mistrz zręcznej polityki, „Nasz Przemyśl" 2009, nr 8, s. 41.

Słownik artystów polskich i obcych w Polsce działajacych. Malarze, rzeźbiarze, graficy, t. 1, A-C, Wrocław 1971; t. 5, Le-M, Wrocław 1993.

Stownik biograficzny adwookatów polskich, t. 1, z. 1-5, Warszawa 1980-1985; t. 2, z. 1-4, Warszawa 1988-2007.

Słownik biograficzny techników polskich, z. 1-24, Warszawa 1989-2013.

Stownik historyków polskich, Warszawa 1994. 
Stańczyk E., Ignacy Przybyłkiewicz 1846-1898, w: B. Sawczyk, M. Sąsiadowicz, E. Stańczyk, Ocalić od zapomnienia... Patroni tarnowskich ulic, t. 2: O-Ż, Tarnów 2004, s. [34-36].

Szarejko P., Słownik lekarzy polskich XIX wieku, t. 1-6, Warszawa 1991-2001.

Umiński W., Biblioteka Zgromadzenia Księży Misjonarzy w Krakowie na Stradomiu przeszłość i teraźniejszość, „Bibliotheca Nostra” 2009, nr 2 (18), s. 35-49.

Z korespondencji Jacka Malczewskiego. Listy Jacka Malczewskiego do Piotra Hubala Dobrzańskiego, oprac. D. Kudelska, „Rocznik Historii Sztuki” 1990, t. 18, s. 259-290.

Karol Libelt and his research journey to Galicia (Poland) in 1869 and the hand written notes prepared for a commemorative book to mark the event currently held in the collection of the Raczyński Library in Poznań

\begin{abstract}
In 2012, the Special Collections Department of the Raczynski Municipal Library in Poznan received a hand written volume (call number ms. 4498) documenting a research journey made by Karol Libelt in Galicia (Poland) in 1869. Shortly after his journey, the philosopher visited Kraków and Lwów with a series of lectures and was warmly received in both cities by the general public. On 17 April 1869, Karol Libelt was given an album, as a token of appreciation and thankfulness, with pages signed by 348 students of the Jagiellonian University and the Technical University in Cracow. The present article discusses the journey made by Libelt to Galicia and the album with the inscriptions of the Cracow students, including Michał Hieronim Bobrzyński, Karol Stanisław Olszewski, Tadeusz Browicz, Józef Krzepela and Piotr Hubal Dobrzański.
\end{abstract}

Key words: Karol Libelt (1807-1878), research journey to Galicia in 1869, Kraków, Lwów, Jagiellonian University, Technical Institute in Cracow, Poland in the 19th. c., Raczyński Library in Poznań, manuscripts, commemorative albums. 
